\title{
Dimethyl sulfoxide: a central player since the dawn of cryobiology, is efficacy balanced by toxicity?
}

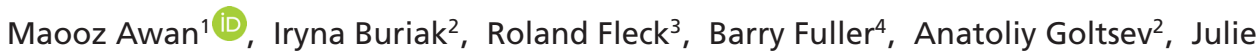 \\ Kerby $^{5}$, Mark Lowdell ${ }^{6}$, Pavel Mericka7, Alexander Petrenko², Yuri Petrenko ${ }^{8}$, Olena \\ Rogulska², Alexandra Stolzing ${ }^{9}$ \& Glyn N Stacey*,10,11,12 iD \\ ${ }^{1}$ Institute for Liver \& Digestive Health, UCL Division of Medicine, Royal Free Hospital, UCL, London, NW3 2PF, UK \\ 2 Institute for Problems of Cryobiology \& Cryomedicine, National Academy of Sciences of Ukraine, Pereyaslavska 23, 61016, Kharkiv \\ ${ }^{3}$ Centre for Ultrastructural Imaging, Kings College London, London, SE1 1UL, UK \\ ${ }^{4}$ Department of Surgical Biotechnology, UCL Division of Surgery, Royal Free Hospital, UCL, London, NW3 2QG, UK \\ ${ }^{5}$ Cell \& Gene Therapy Catapult, 12th Floor Tower Wing, Guy's Hospital, Great Maze Pond, London, SE1 9RT, UK \\ ${ }^{6}$ Centre for Cell, Gene \& Tissue Therapy, Royal Free London NHS FT \& UCL, London, NW3 2PF, UK \\ ${ }^{7}$ Tissue Bank, University Hospital Hradec Kralové, Czech Republic \\ ${ }^{8}$ Department of Biomaterials \& Biophysical Methods, Institute of Experimental Medicine of the Czech Academy of Sciences, \\ Prague, Czech Republic \\ ${ }^{9}$ University of Loughborough, Centre for Biological Engineering, Loughborough University, Holywell Park, Loughborough, UK \\ ${ }^{10}$ International Stem Cell Banking Initiative, 2 High Street, Barley, Hertfordshire, SG8 8HZ \\ ${ }^{11}$ Beijing Stem Cell Bank, Institute of Zoology, Chinese Academy of Sciences, 25-2 Beishuan West, Haidan District, 100190 Beijing, \\ China \\ ${ }^{12}$ Institute of Stem Cells \& Regeneration, Chinese Academy of Sciences, Beijing 100101, China \\ *Author for correspondence: glyn.stacey@iscbi.org
}

Dimethyl sulfoxide (DMSO) is the cryoprotectant of choice for most animal cell systems since the early history of cryopreservation. It has been used for decades in many thousands of cell transplants. These treatments would not have taken place without suitable sources of DMSO that enabled stable and safe storage of bone marrow and blood cells until needed for transfusion. Nevertheless, its effects on cell biology and apparent toxicity in patients have been an ongoing topic of debate, driving the search for less cytotoxic cryoprotectants. This review seeks to place the toxicity of DMSO in context of its effectiveness. It will also consider means of reducing its toxic effects, the alternatives to its use and their readiness for active use in clinical settings.

First draft submitted: 22 November 2019; Accepted for publication: 27 March 2020; Published online: 28 April 2020

Keywords: cell therapy $\bullet$ cell therapy safety $\bullet$ cryobiology $\bullet$ cryopreservation $\bullet$ cryoprotectants $\bullet$ cryoprotectant toxicity $\bullet$ dimethyl sulfoxide $\bullet$ DMSO toxicity

Dimethyl sulfoxide ( $\mathrm{Me}_{2} \mathrm{SO}$; commonly referred to as DMSO) has been a keystone agent in the development of applied cryobiology over the past 50 years. The use of DMSO as a cryoprotectant capable of mitigating freezing-related cell injuries was first documented by Lovelock and Bishop during slow cooling of bull sperm [1].

As a dipolar aprotic solvent (i.e., a solvent that cannot donate a hydrogen bond), DMSO has an array of properties that allow its participation in numerous chemical reactions. This chemical versatility has been studied for many decades [2-4]. It is beyond the scope of this review to detail these and further information can be found elsewhere [5]; but in brief, the agent has strong molecular stability, a high dielectric constant, properties of basicity, solvation of salts, particularly anions and a propensity to act as the acceptor atom in hydrogen bonding, in other words, aprotic. From earliest studies, it was estimated that a hydrogen bond between DMSO and water is stronger by about 30\% than that between two water molecules [2]. It was also shown that DMSO could protect both against biological injuries sustained during cryopreservation and against some aspects of radiation injury [6]. Against this backdrop of intensive study of DMSO in the 1950's and 1960's, it is perhaps not so surprising that Lovelock and Bishop took Future 
forward studies on cryopreservation using the agent. Over the next 20 years, several comprehensive reviews on the chemistry and pharmacology of DMSO were produced [5,7]. Readers are directed to these for further insights.

Pure DMSO is a clear colorless liquid, which crystallizes at $+18.5^{\circ} \mathrm{C}$, and is hygroscopic and exothermic when mixed with aqueous solutions. The property of strong hydrogen bonding with water imparts its antifreeze characteristics. DMSO can readily pass through biological membranes largely with minimal evidence of injury, has widespread solvation properties [5] and has found utility as a vehicle for clinical drug administration and dissolving water-insoluble compounds for test systems. Metabolic products of DMSO (notably dimethyl sulfide) frequently impart a perceived bitter taste and a breath odor similar to garlic [8], which has often raised questions about personal acceptance of therapies involving DMSO, for example, when using the chemical as a solvent for topical applications of different drugs. Pharmacological effects such as nephrotoxicity and ocular toxicity have been reported in experiments where repeated high daily oral or dermal dosing was performed [5]. The impact of DMSO in multiple organisms and biological systems has also been reported by Shu et al. [9].

Table 1 shows highlights for some of these effects. However, the direct relevance of these observations for cryobiological applications of DMSO is questionable.

This current review will attempt to examine the evidence for and against the biological impacts of the use of DMSO as practiced in modern cryopreservation protocols, with particular reference to clinical applications.

\section{DMSO into cryopreservation studies}

Following the report by Lovelock and Bishop [1], other contemporaneous studies were made into the cryobiological applications of DMSO and the potential pharmacological changes of the agent under the same exposure conditions. For example, Farrant et al. studied cryopreservation of smooth muscle preparations, and reported absence of any specific pharmacological responses, but did note some nonspecific osmotic damage [28]. This was one of the earliest reports to highlight one of the issues which have confused discussions about DMSO toxicity in cryopreservation - the potential osmotic injuries incurred when loading and unloading cells and tissues with any cryoprotective agent (CPA) - not only DMSO - in the concentrations required for cryopreservation (frequently at levels of $10 \%$ $\mathrm{w} / \mathrm{v}$ or around $1 \mathrm{M}$ ), versus any specific molecular alterations dependent on DMSO chemistry. In the same era, Ashwood-Smith et al. (1964) reported successful cryopreservation by slow cooling of murine lymphocytes and storage for 3 months at $-196^{\circ} \mathrm{C}$ using DMSO concentrations up to $15 \%(\mathrm{w} / \mathrm{v})$ [29]. In the following years, slow cooling cryopreservation using DMSO was applied to a range of cells (mostly blood cell subsets) and tissues [30-35]. Today hematopoietic stem cell (HSC) transplantation has become well-established procedure for treatment of many disorders of the hematopoietic system. According to the European society of Blood and Marrow Transplantation (EBMT) survey, in 2014 more than 40,000 transplants have been performed in European countries, with more than $55 \%$ of them being autologous and thus requiring cryopreservation [36]. The main indications for HSC transplantation are leukemias, lymphoid neoplasias including non-Hodgkin lymphoma (NHL), solid tumors and nonmalignant disorders. Many of these require either autologous stem cell transplantation or umbilical cord blood (UCB) HSC infusion after high-dose chemotherapy and require the inclusion of mandatory cryopreservation step into the treatment protocol.

\section{Biological \& clinical impact of DMSO}

Having confirmed cryoprotective properties and ensuring high viability of cells post-thaw, the direct administration of DMSO-containing cellular products can be associated with a number of well-identified side effects and shortcomings [37]. According to the EBMT analysis, around 30-60\% DMSO-containing transplants are associated with at least one side effect or complication [38,39]. The most common are nausea, vomiting, hypertension/hypotension, sedation or headache [38]. However, there is evidence of more serious complications such as cardiac arrhythmia, encephalopathy, acute renal failure, bronchospasm and neurologic disorders. The direct infusion of highly osmolar (around $1400 \mathrm{mOsmol}$ for 10\% DMSO, compared with $\sim 290 \mathrm{mOsm}$ for serum) solution into the isotonic environment such as blood, will result in the significant water uptake by the infused cells and subsequent detrimental changes in cell homeostasis, leading to apoptosis and cell death [40]. In this case, the efficiency of the transplantation will be significantly decreased or it will fail completely. Such observations have driven the clinical and research institutions to search for ways of minimizing these potentially hazardous effects by either reducing the concentration of DMSO, removing the cryoprotectant from the cryopreserved cell-containing grafts prior to application (as described in section 5 below) or replacing DMSO with an alternative cryoprotectant. 
Table 1. Examples of reported biological effects of dimethyl sulfoxide across a range of biological systems.

\begin{tabular}{|c|c|c|c|}
\hline Cell type/line & DMSO & $\mathrm{T}^{\circ} \mathrm{C}$ & Effect \\
\hline \multicolumn{4}{|l|}{ Microorganisms } \\
\hline Saccharomyces cerevisiae BY4743 & & Cryot $^{\circ}$ & $\begin{array}{l}\text { - Increasing expression of genes responsible for synthesis of proteins, } \\
\text { ergosterol, cell wall biosynthesis, ribosomal biosynthesis, accumulation of } \\
\text { low molecular weight substances (glycerol, arginine, proline) } \\
\text { - Downregulation of genes involved in } \beta \text {-oxidation of fatty acids }\end{array}$ \\
\hline \multicolumn{4}{|l|}{ Stem cells } \\
\hline $\begin{array}{l}\text { Human embryonic stem cells HUES-7, } \\
\text { foreskin-derived mesenchymal stem } \\
\text { cells }\end{array}$ & $\begin{array}{l}0.01,0.1,1.0 \% \\
(v / v)\end{array}$ & $\mathrm{RT}^{\circ}$ & $\begin{array}{l}\text { - Dose-dependent changes in cell viability, morphology, adhesion and gene } \\
\text { expression: inhibition of embryoid bodies formation, decrease in adhesion, } \\
\text { cell death } \\
\text { - Low and medium DMSO doses upregulate mesodermal markers } \\
\text { - Higher DMSO doses downregulate ectodermal differentiation }\end{array}$ \\
\hline $\begin{array}{l}\text { Human umbilical cord blood stem } \\
\text { cells }\end{array}$ & $\begin{array}{l}40 \%, 10 \% \text { and } \\
\text { DMSO removal }\end{array}$ & $\begin{array}{l}\mathrm{RT}^{\circ} \text { and post } \\
\text { thaw }\end{array}$ & $\begin{array}{l}-40 \% \text { DMSO lethal. } 10 \% \text { DMSO no viability reduction after } 1 \mathrm{~h} . \mathrm{DMSO} \\
\text { washout improved viability } \\
\text { Optimum } 7.5-10 \%\end{array}$ \\
\hline \multicolumn{4}{|l|}{ Immune cells } \\
\hline $\begin{array}{l}\text { Undifferentiated pre-B and pre-T } \\
\text { (RPMI-8402) lymphoid cells }\end{array}$ & $\begin{array}{l}1.5 \%(v / v) \\
24-72 h^{\dagger}\end{array}$ & & $\begin{array}{l}\text { - B-cells are resistant to DMSO } \\
\text { - Increased membrane fluidity, cytosolic } \mathrm{Ca}^{2+} \text {, NOS activity } \\
\text { - Reversible G1 growth arrest of T cells, increased apoptosis, changes in TdT } \\
\text { expression } \\
\text { - Alterations in CD external antigens, TdT, TCR, RAG-1 expression, involved in } \\
\text { growth arrest, decrease in c-myc expression, ODC activity and intracellular } \\
\text { polyamine content, inappropriate differentiation leading to apoptosis } \\
\text { triggering }\end{array}$ \\
\hline
\end{tabular}

\section{Neural cells}

Retinal neuronal cell line $\quad 1,2,4,8 \%(v / v) \quad$ - Caspase-3 independent death of neurons

- Inhibition of mitochondrial respiration, increase of cytosolic $\mathrm{Ca}^{2+}$, phosphatidylserine externalization, translocation of apoptosis-inducing factor (AIF) from mitochondria to the nucleus, PARP activation, DNA fragmentation

\begin{tabular}{|c|c|c|c|}
\hline Rat hippocampal cells & $0.5,1 \%(v / v)$ & Neurodegeneration, apoptosis & [18] \\
\hline Astrocytes & $\begin{array}{l}1-5 \% \\
24 \mathrm{~h}^{\dagger}\end{array}$ & $\begin{array}{l}\text { - Decreased survival and viability of astrocytes ( }>1 \% \text { DMSO) } \\
\text { - Mitochondria swelling. Decrease in mitochondrial membrane potential. } \\
\text { Cytochrome C release from mitochondria. Increased ROS formation } \\
\text { - Apoptosis. Increased caspase- } 3 \text { expression, decreased anti-apoptotic } \\
\text { protein Bcl-2 and procaspase- } 3 \text { expression }\end{array}$ & [19] \\
\hline \multicolumn{4}{|l|}{ Hepatic cells } \\
\hline Rat primary hepatocytes & $1 \%$ & $\begin{array}{l}\text { - Prolonged pre-apoptotic phase in hepatocytes due to } 24 \text {-h post-isolation } \\
\text { DMSO treatment. Redistribution of caspase- } 9 \text { from the nucleus to cytosol } \\
\text { - Delayed apoptosis triggering }\end{array}$ & [20] \\
\hline \multicolumn{4}{|l|}{ Blood cells } \\
\hline $\begin{array}{l}\text { PBMC; } \\
\text { MM6, RAW } 264.7\end{array}$ & $\begin{array}{l}0.25,0.5,1,2, \quad 37^{\circ} \mathrm{C} \\
4 \%\end{array}$ & $\begin{array}{l}\text { - DMSO concentration of } 4 \% \text { suppresses ROS and IL- } 6 \text { production in all cell } \\
\text { types (leukocytes and RAW } 264.7 \text { are the most sensitive). } 0.25 \text { and } 0.5 \% \\
\text { DMSO stimulate ROS and IL- } 6 \text { formation in MM6 }\end{array}$ & [21] \\
\hline Red blood cells & $\begin{array}{l}0.2,0.4,0.6 \% \\
0-72 \mathrm{~h}^{\dagger}\end{array}$ & - Increased hemolysis at $0.2 \%$ DMSO after $6 \mathrm{~h}$ and at $0.4 \%$ after $0 \mathrm{~h}$ & [22] \\
\hline Platelets & $0.25-6 \%$ & - Inhibition of aggregation, decreased thrombin generation & [22] \\
\hline EAhy926 cells $\ddagger$ & $\begin{array}{l}0.2,0.4,0.6 \% \\
0-72 \mathrm{~h}^{\dagger}\end{array}$ & - Decreased proliferation, growth arrest at G1 phase, increased apoptosis & [22] \\
\hline \multicolumn{4}{|l|}{ Cancer cells } \\
\hline Monocytes and T leukemic cells & $\begin{array}{l}0.1,0.2,0.5,1,2,37^{\circ} \mathrm{C} \\
5 \%\end{array}$ & $\begin{array}{l}\text { - Time- and concentration-dependent DMSO cytotoxicity. DMSO } \\
\text { concentrations } \geq 2 \% \text { cause decreased proliferation after } 24 \text {-h incubation }\end{array}$ & [23] \\
\hline Promyelocytic leukemic HL-60 cells & $\begin{array}{l}1.25 \% \\
6 \mathrm{~d}^{\dagger}\end{array}$ & $\begin{array}{l}\text { - Inhibited proliferation at the day } 2 \text { DNA degradation } \\
\text { - Chromatin condensation and nuclear fragmentation } \\
\text { - Apoptosis in terminal differentiated HL-60 }\end{array}$ & [24] \\
\hline HL-60 cells & $0.25-1 \%$ & - Stimulation of ROS production & [21] \\
\hline HeLa cells & $\begin{array}{l}0.1-15 \%(v / v) \\
72 h^{\dagger}\end{array}$ & - Decrease in cell number, growth suppression, alteration of cell shape & [25] \\
\hline $\begin{array}{l}\text { Colon adenocarcinoma tumor cells } \\
\text { Caco } 2 / \mathrm{TC} 7\end{array}$ & $2-100 \%$ & - LDH release from cells at DMSO concentration $>10 \%$ & [26] \\
\hline $\begin{array}{l}\text { Human embryonal carcinoma NEC-8 } \\
\text { and NEC-14 lines }\end{array}$ & $0.2-1 \%$ & $\begin{array}{l}\text { - Increased DNA methylation, aberrant differentiation, downregulation of } \\
\text { stemness markers and resistance to cisplatin }\end{array}$ & [27] \\
\hline $\begin{array}{l}\text { †Incubation time. } \\
\text { ‡Hybridoma cell lines from umbilical vas } \\
\text { MM6: Mono Mac 6: PBMC: Peripheral b }\end{array}$ & $\begin{array}{l}\text { endothelial cells and lung } \\
\text { mononuclear cells; ROS: Re }\end{array}$ & $\begin{array}{l}\text { xhibiting properties of vascular endothelial cells. } \\
\text { n species. }\end{array}$ & \\
\hline
\end{tabular}


Direct in vivo inoculation of DMSO into rat pups has been shown to elicit significant dose-dependent neurotoxic effects evidenced by increased levels of apoptosis in neural cells, the severity of which was age related $[17,18]$. The toxicity of DMSO for T cells and monocytes seems to be responsible for the observed anti-inflammatory and anti-oxidant effects of DMSO [23] and this has been confirmed from other data showing the key role of DMSO to be reduction of IL- 6 and reactive oxygen species (ROS) in leucocytes [21], rather than free radical scavenging. While levels of DMSO in the order of $0.1 \% \mathrm{v} / \mathrm{v}$ are capable of suppressing cell growth, short incubation periods are not believed to incur permanent significant effects [25]. In clinical use, exposure of hematopoietic stem cells (HSC) to DMSO at a level of $5-10 \% \mathrm{v} / \mathrm{v}$ for $1-2 \mathrm{~h}$ has been shown not to be toxic [41,42]. Reduction of DMSO to $5 \%$ has been reported to achieve improved engraftment recovery times for leucocytes, neutrophils and platelets [43], while in hematopoietic stem cell preparations this level of DMSO compared with $10 \%$ also promotes colony-forming capacity [44], reduces side effects in patients, promotes levels of CD34+ cells and reduces cell death [45,46].

On exposure to DMSO a range of effects are observed, in a variety of cell types, specifically on the plasma membrane including changes in membrane fluidity in RPMI-8402 cells [13], induction of membrane dysfunction in colon tumor cells [26], leading to loss of lipid asymmetry and flipping of phosphatidylserine in retinal neuronal cells $[13,17]$. In colon cancer cells, DMSO at the concentration of $0.1 \%(\mathrm{v} / \mathrm{v})$ can change secondary structure of proteins, decrease cholesteryl esters in membrane lipids and affect their oxidation status [47]. These membrane effects impact on important transport systems, resulting in changes of cytosolic $\mathrm{Ca}^{2+}$ levels $[13,17]$ and translocation of specific messengers involved in mRNA transcription and cell differentiation [48]. Ultimate consequences of these effects are arrested cell growth and programmed cell death. However, the biological effects of DMSO are not limited to the plasma membrane and under specific conditions, can include induction of changes in cytoskeleton [11], oocyte microfilaments [49] microtubules [50] and chromatin changes [13,47] as well as induction of cellular differentiation [47,51].

The capacity of DMSO to elicit a wide range of effects on cell biology may point to potential concerns around its use in clinical practice. Numerous cell types have shown adverse biological impact of exposure to DMSO (Table 1). For example, a range of blood-borne cell types have shown increased expression of IL-6 and ROS at levels of DMSO, as low as $0.2 \%(\mathrm{v} / \mathrm{v})$ [21]. Studies on early lineage B- and T-cells have proven to be more sensitive to DMSO (1.0\% v/v for 24-72 h) showing increased apoptosis, reversible growth arrest and inappropriate differentiation. Adverse impact of DMSO on functionality of nominally nonleucocyte blood components have also been reported such as increased hemolysis of erythrocytes, inhibited disaggregation and decreased thrombin in platelets [22] at similarly low levels of DMSO $(0.2 \% \mathrm{v} / \mathrm{v})$. Human stem cells (human embryonic and tissue-specific stem cells [52] otherwise known as mesenchymal stem [or stromal] cells [MSCs)] show dose dependent $(0.1-1.0 \%$ $\mathrm{v} / \mathrm{v}$ DMSO) effects of DMSO at room temperature on viability, morphology, adhesion and differentiation [48]. Alteration in apoptotic responses has also been reported in rat primary hepatocytes [20] while in a range of neural cell types, exposure to DMSO (at $0.5-8.0 \% \mathrm{v} / \mathrm{v}$ ) can either promote or decrease apoptosis [17-19]. Even potentially more robust cancer cell lines have shown a range of effects on ROS levels [21], growth rate and cell viability [22-26] or aberrant differentiation [27]. Microorganisms are also not immune to the effects of DMSO which is reported to influence expression of a range of genes relevant to cell metabolism and all cell integrity [10].

It should be noted that some of the effects of DMSO, other than for cryoprotection, have been put to good use in cell cultures. For example, DMSO has been commonly used as an inducer of cellular differentiation probably associated with its ability to cause chromatin condensation [13] and alter gene expression [48,51,53,54]. This property has been employed for in vitro assays to provide a mature cellular phenotype [51,54] and to establish continuous cell lines with irreversibly different characteristics [51].

The DMSO effects described above were observed in noncryopreserved cells. Similar results were obtained for cryopreserved fetal liver cells (reduction in stemness genes NANOG, OCT4 and SOX2 expression) [55], bone marrow cells (structural and functional changes in cells) [56].

\section{Secondary cryoprotective agents reducing DMSO}

One way to mitigate potential or perceived problems of toxicity when using DMSO in cryopreservation is to supplement the cryoprotective agents (CPA) mixture with other agents which themselves have cryoprotectant effects (all-be-it at often lower efficiency than DMSO itself), but which provide an opportunity to reduce the overall DMSO concentration. Cryobiologists have experimented with such mixtures for more than 40 years [57], and while combinations with other CPAs such as glycerol and polypropylene glycol have been used, their addition to DMSO has been addressed here and in particular in Section 3. Oligosaccharides used in association with DMSO. 
Among a wide variety of molecules with cryoprotective properties, naturally occurring sugars merit special attention. Their addition to CPA formulations is intended to increase cell dehydration and lessen the required concentration and time of exposure to DMSO. Application of monosaccharides in cryopreservation is less common than disaccharides, due to the possibility of nonenzymatic glycosylation of cell proteins and lipids that may alter their functions. Nevertheless, numerous studies have reported the efficiency of glucose containing methanol solutions for cryopreservation of sperm [38,39].

Disaccharides, in contrast, are widely used as nonpermeating CPA supplements for freeze drying, vitrification and slow freezing of various cell types [40]. Nonreducing disaccharides, particularly trehalose and sucrose, are known to have higher glass transition temperatures compared with DMSO, ethylene glycol and 1,2-propandiol [58]. This property ensures the formation of a uniform glass structure with high viscosity and low motility, thus, restricting molecular interactions and lowering the cell damage during rapid freezing [59].

At slow cooling rates, the main causes of cell injury are prolonged exposure to hypertonic environment and the growth of extracellular ice crystals. Inclusion of disaccharides into the CPA composition, on the one hand, can significantly influence the morphology, shape and size of ice crystals, which, in turn, affects cell survival [60]. On the other hand, hydroxyl groups of disaccharides can interact with the hydrophilic part of proteins and lipid head groups, thus stabilizing membranes and preventing their damage upon dehydration [61,62]. Recently, it has been shown that trehalose does not directly interact with proteins but instead played a role in compaction and stabilization of molecules by decreasing their hydration [63,64]. However, the exact mechanism for improvement of post-thaw cell survival in the presence of sugars in CPAs remains uncertain.

Since there are no specific transporters for disaccharides in mammalian cells, when added into CPA they tend to remain in the extracellular space. In this case, their cryoprotective action is insufficient to ensure the preservation of structural and functional integrity of cells. Meanwhile, application of disaccharides with permeating cryoprotectant such as DMSO, even in low concentrations, can significantly improve the cryopreservation outcome.

Combination of $0.2 \mathrm{M}$ trehalose and $0.5 \mathrm{M}$ DMSO has been shown to be effective for long-term storage of adipose aspirates [65]. Cells isolated from lipo-aspirates immediately after thawing had slightly retained growth rate compared with fresh ones, however, this difference lessened during the following cell culture. Comparable results were obtained using $6 \%$ trehalose, $4 \%$ DMSO and $90 \%$ fetal bovine serum (FBS) for cryopreservation of adipose tissue-derived MSCs (tissue-specific progenitor cells [52]) [66]. MSCs frozen for 6 and 12 months showed the viability of 80 and $70 \%$, correspondingly. After being thawed and plated, cells started to proliferate and were capable of differentiation into adipogenic and endothelial lineages.

Solutions with trehalose and a reduced concentration of DMSO have been successfully used for cryopreservation of hematopoietic stem cells $[67,68]$. Samples cryopreserved with $2.5 \%$ DMSO without disaccharide showed a significant reduction in viability and clonogenic potential compared with those cryopreserved with trehalose or with 10\% DMSO (control group). Application of another nonreducing disaccharide, sucrose, as a cryoprotectant for hematopoietic stem cells of umbilical cord blood and fetal liver was also effective [67,69]. For instance, the inclusion of $0.3 \mathrm{M}$ sucrose as an additive to the CPA containing 5\% DMSO resulted in a significant reduction of human fetal liver cell loss during cryopreservation, increased metabolic activity and function (the number of the myeloid-macrophage colonies). The recovery rate of cells cryopreserved under protection of $5 \%$ DMSO and $0.3 \mathrm{M}$ sucrose mixture was $20 \%$ higher than without sugar and did not significantly differ from $10 \%$ DMSO alone [69]. However, the efficiency of sucrose to reduce DMSO concentration seems to be lower than that of trehalose. Sucrose inclusion into CPA allowed reduction of the DMSO concentration to only $5 \%$ while for trehalose similar viability results were obtained with 2.5\% DMSO [67]. Experiments carried out by the group of Mantri et al. [70]. have shown comparable data: CPA containing $0.2 \mathrm{M}$ trehalose with $2 \%$ DMSO was superior that the one with sucrose and DMSO in the same concentrations based on post-thaw viability results and assessment of hematopoietic colony formation.

Saccharides have been proven to be excellent candidates for cryopreservation of hepatocytes. Yang et al. [71] tested three sugars (glucose, sucrose and trehalose) and three sugar alcohols (xylitol, maltol and sorbitol) for improvement of the metabolic function of human hepatocytes that were cryopreserved using DMSO reduced to $5 \%$ concentration. Cell viability, post-thaw attachment rate and metabolic activity (albumin, glucose, urea metabolism) of cryopreserved hepatocytes were enhanced by the addition of $0.4 \mathrm{M}$ sorbitol into $5 \%$ DMSO solution. The authors concluded that the mixture of 5\% DMSO and $0.4 \mathrm{M}$ sorbitol can replace $10 \%$ DMSO in CPA for cryopreservation of human hepatocytes. Recent data obtained by Cardoso, et al. [72] have indicated the positive effect of saccharides (sucrose, glucose and trehalose) on hepatocytes post-thaw viability when they 
were used in combination with 5\% DMSO. Among the different tested sugars, trehalose showed the best overall outcome.

To increase cell viability after cryopreservation under the protection of saccharides and low nontoxic DMSO concentrations, CPA can be additionally supplemented with antioxidants such as, catalase, superoxide dismutase, glutathione, vitamin $\mathrm{C}$ and vitamin $\mathrm{E}$. This approach has been tested on human HSCs and amniotic fluid-derived stem cells. It was demonstrated that a solution containing $60 \mathrm{mmol} / \mathrm{l}$ trehalose, $2.5 \% \mathrm{DMSO}$, and $100 \mu \mathrm{g} / \mathrm{ml}$ catalase produced results similar to those for $10 \%$ DMSO in terms of survival, proliferation, and expression of stem cell markers in cryopreserved amniotic fluid-derived stem cells [73].

Reduction of DMSO concentration to a nontoxic level might be reached not only by addition of saccharides into CPA but is also feasible by preliminary cell loading with sugars. In this case, saccharides can ensure cell preservation during freezing acting as permeating cryoprotectants.

In order to achieve loading of relatively large sugar molecules into cells, several approaches have been proposed. Earlier techniques using microinjection and electroporation were associated with increased risk of cell damage [74,75]. In the case of electroporation, the observed cell damage can be mitigated by optimizing the electric field characteristics as shown by Dovgan et al. [76]. In that instance, human adipose tissue-derived cells loaded with trehalose by reversible electroporation had high survival rates and maintained their functional characteristic after freezing. Recently, proposed methods for saccharide loading are mainly based on the use of genetic engineering to create modified cell membrane pores or to insert disaccharide biosynthetic genes into the cell genome, which can be time consuming and require additional manipulations $[77,78]$.

An alternative protocol for sugar loading in which a critical step is cell culture in the presence of disaccharide prior to cryopreservation, was shown by Oliver et al. [79]. Their data demonstrated that MSCs were capable to upload trehalose from extracellular space by a clathrin-dependent fluid phase endocytotic mechanism. The same approach has been utilized for DMSO-free cryopreservation of endothelial cells and it allowed to achieve high post-thaw cell metabolic activity [80]. This protocol was considered to be potentially applicable not only for trehalose but for other disaccharides as well.

Recently, it has been confirmed that inclusion of mannitol, lactose, sucrose, trehalose and raffinose into the culture medium for $24 \mathrm{~h}$ prior to freezing resulted in a significant increase of human dermal MSCs (tissue-specific progenitor cells) survival [81]. The authors claimed that optimal concentration of disaccharides in extracellular space for cell pretreatment (loading phase) was $0.2 \mathrm{M}$. Nonetheless, culture of human adipose tissue-derived MSCs in the presence of sucrose in the same concentration led to cell lysis by osmotic shock [82]. Positive results were achieved when using a solution containing $0.1 \mathrm{M}$ of sucrose. These observations point to the need for screening of optimal sugar concentration and exposure time for each specific cell type.

In conclusion, the cryoprotective effect of saccharides in a wide variety of biological systems has been confirmed in numerous studies and when combined with relatively low concentrations of DMSO, they are capable to preserve both structure and function of frozen cells.

\section{Supplementation of DMSO with high molecular weight macromolecules}

Mixtures of DMSO with high molecular weight macromolecules may have some advantages over solutions containing DMSO alone. During a relatively short time of equilibration required for penetration of DMSO into a cell, high molecular weight agents do not penetrate and act by extracellular mechanisms. The cryoprotection of cells is elicited by their ability to absorb water and confine osmotic gradients. As polymers are high molecular weight macromolecules which lower the freezing point (on the basis of kinetics of cooling), they permit avoidance of excess supercooling and reduce the cooling rate required for cell survival. These properties combined with high viscosities at low temperature, prohibit water molecules from forming ice crystals outside the cell during cooling and suppress recrystallization during thawing [83]. Due to different mechanisms of action of nonpenetrative high molecular weight agents added together with penetrative DMSO into a cryoprotective solution, there may be an additive effect resulting in reduction of DMSO concentration required for cell cryoprotection.

Mixtures of high molecular weight macromolecules in combination with DMSO and other penetrative CPAs, are frequently used for cryopreservation of the most biological objects by vitrification. Here we put attention on conventional slow freezing cryopreservation as an approach that allows to reveal a potential of individual high molecular weight macromolecules to enable the use of reduced DMSO concentration and, thus, minimize the toxic effect of this cryoprotectant. 
Among a wide variety of high molecular weight agents for cryobiological projects, preference should be given to those that have proven biocompatibility in cell culture practice and/or approved for clinical application. FBS is a common supplement in culture media which contains proteins, growth factors and hormones and promotes cell adhesion and proliferation. FBS in concentrations from 10 to $90 \%$ in combination with $10 \%$ DMSO is usually included into CPA. Bovine serum albumin (BSA) is a major component of FBS that provides its cryoprotective efficiency due to stabilization of osmotic pressure and protection of cells during freezing and thawing. Thereby, FBS can contribute to reduction of DMSO concentration. Thus, Zhao et al. [84] have shown that the use of either $20 \%$ FBS or $70 \%$ FBS in combination with $5 \%$ DMSO produced similar results to combination with $10 \%$ DMSO for recovery of fetal human liver $\mathrm{CD} 34^{+}$cells after conventional slow freezing cryopreservation.

Due to its xenogeneic origin, the US FDA does not permit the use of FBS in products intended for humans. This problem can be avoided by using autologous or allogeneic human serum, although obviously this must be screened for human pathogens. Mitchell et al. [85] compared viability, morphology, growth and capacity to multilineage differentiation of equine MSCs after cryopreservation with either FBS or autologous or allogeneic serum. It has been shown that an allogeneic or autologous serum can be used for animal component-free MSC cryopreservation. Moreover, independently of the source of serum (autologous, allogeneic or xenogeneic) their presence in freezing media in combination with DMSO reduced to $5 \%$ was sufficient to preserve viability and growth of MSCs at the level of $10 \%$ DMSO.

Many disadvantages associated with the use of serum, such as inconstant quality, variation in composition among serum lots, risk of pathogenic contamination, high cost etc., drive the development of serum-free (cryopreservation media suitable for clinical-grade cell banking. Though the roles of individual components of serum have not been fully determined, proteins seem to play a key role in its cryoprotective properties. For replacement of FBS in culture media, the protein sericin, derived from the silkworm cocoon, was proposed by Terada et al. [86]. It has been reported that addition of sericin in culture medium promoted cell attachment and proliferation, stimulated the synthesis of collagen and demonstrated antioxidant and mitogenic activities [87]. Sericin has been successfully used also for cryopreservation of various cell types [87-89]. Sericin at a concentration of $1 \%$ in the freezing medium containing $10 \%$ DMSO, may substitute FBS for cryopreservation of human MSCs, but is not effective with reduced DMSO concentration [90]. On the other hand, the combination of $1 \%$ sericin and 7\% DMSO in CPA ensured similar survival rate and function (insulin secretion) of rat pancreatic islets compared with 10\% DMSO with FBS [91]. After transplantation, islets cryopreserved with either $10 \%$ DMSO or $7 \%$ DMSO in combination with $1 \%$ sericin indicated similar results in blood glucose control and renal subcapsular engraftment. Given these results, it seems that supplementation of CPA with sericin could allow reduction in DMSO concentration.

Among synthetic high molecular weight macromolecules, there are advantageous examples that are able to biodegrade in vivo after cell transplantation or transfusion, thus avoiding the need to remove them after cryopreservation. Hydroxyethyl starch (HES) is one such molecule that exhibits colloidal properties similar to human albumin and is widely used as a plasma substitute in adults for the treatment of shock caused by hemorrhage, burns, sepsis, ischemia/reperfusion and other injuries [92]. HES is metabolized by amylase and HES fragments are subsequently eliminated from the circulation after infusion. HES is free of side effects and often has been used in cryopreservation protocols. Properties of HES as a cryoprotectant have been reviewed by Stolzing et al. [93]. In concentrations $\geq 10 \%$ HES alone has demonstrated highly protective effects for the cryopreservation of keratinocytes [94,95], bone marrow cells [96], Chinese hamster cells [97], red blood cells of human [98,99], domestic animal origin [100] as well as other cells. A comparative evaluation of HES and DMSO as cryoprotectants was performed and in two studies, Ashwood-Smith et al. have shown that HES alone is less effective than DMSO [97,101]. Many more papers have focused on the admixture of HES with other CPAs including DMSO. Naaldijk et al. [102] have confirmed that HES alone could not provide sufficient cryoprotection of rat MSCs, but in combination with DMSO was effective. Using several cooling protocols, it has been shown that the supplementation of CPA with $5 \%$ of HES permitted reduction of DMSO concentration to 5\%, although the highest viability of MSCs after post-thaw recovery in culture was observed using the mixture of $8 \%$ DMSO and 2\% HES. It is interesting that the cryopreservation with HES of different molecular weights in the range from 109 to $609 \mathrm{kDa}$ had a minor effect on survival and differentiation capacity of MSCs. A more recent study of this team has confirmed the ability of HES to facilitate reduction of DMSO concentration for adherent skin tissue cells (fibroblasts and keratinocytes) [103]. Cell lines and primary fibroblasts in suspension and monolayer have been cryopreserved using controlled rate freezing in CPA containing HES, DMSO and FBS. Testing cell number and viability, maintenance of nuclei, actin and mitochondria markers 
it has been shown that cryopreservation of fibroblasts and keratinocytes both in suspension and in monolayer was successful using mixture of 5\% DMSO, 5\% HES and 90\% FBS.

Due to a $6 \%$ HES of average MW $450,000 \mathrm{Da}\left(\operatorname{Hespan}^{\circledR}\right)$ is used for plasma expansion this hetastarch has been most widely studied in cryopreservation projects for reduction of DMSO toxicity. This is primarily related to cryopreservation of hematopoietic stem cells (HSCs). Mixing 5\% DMSO with HES of MW 450,000 Da showed better recovery rates of $\mathrm{CD}_{4} 5^{+}$and $\mathrm{CD} 34^{+}$cells and colony forming unit (CFU) recovery after cryopreservation of HSCs derived from cord blood and peripheral blood than DMSO alone [104]. Cryopreservation of human bone marrow cells by conventional slow rate cooling protocol in CPA containing a combination of $5 \% \mathrm{DMSO}, 6 \%$ HES and 4\% human serum albumin, resulted in better survival and CFU recovery of HSCs in culture compared with $10 \%$ DMSO without serum [105]. Similar results have been obtained on canine bone marrow-derived HSCs cryopreserved using slow rate freezing in CPA containing either 10\% DMSO and 90\% FBS or 5\% DMSO, 6\% HES and 4\% BSA [106]. Cryopreservation in the mixture HES, BSA and reduced concentration of DMSO provided higher post thaw cell viability and CFU recovery rates than $10 \%$ DMSO in fetal serum.

CPA containing HES with a lower average of MW (264,000 vs 450,000 Da) (Pentastarch) in combination with $25 \%$ human albumin and 5\% DMSO has demonstrated high efficiency for cryopreservation of human cord blood HSCs [107]. A randomized Phase III clinical trial has shown that patients who received autologous peripheral blood HSCs cryopreserved with the combination of 5\% DMSO, 6\% HES and 4\% human serum albumin, recovered their white blood cell level more quickly, than those who received peripheral blood (PB)-HSCs cryopreserved with $10 \%$ DMSO and $90 \%$ human serum [108]. This combination has demonstrated efficiency also on dog islets that after cryopreservation in CPA containing 6\% HES and 4\% FBS in composition with reduced to 5\% DMSO maintained a high recovery rate.

In a number of countries, dextran is used clinically in plasma volume expansion, thrombosis prophylaxis and peripheral blood volume enhancement. Ashwood-Smith et al. [109] found that dextran of molecular weight (MW) $70,000 \mathrm{Da}$ in concentration $9 \%$ has provided good protection of $\mathrm{CHO}$ cells cryopreserved with cooling rate approximately $20^{\circ} \mathrm{C} / \mathrm{min}$ in CPA that contained $10 \%$ fetal calf serum. Addition of $1 \%$ DMSO to $9 \%$ dextran yielded survival rates as high as those obtained with 10\% DMSO. In previous experiments of this group [109] performed on the same cell type (Chinese hamster cells) and using the same cryopreservation protocol in the absence of FBS showed no so significant improvement in cryoprotection when using a number of dextrans of average MW 10,000-500,000 Da. This data was corroborated by another report [110], where addition of $10 \%$ dextran of MW 100,000 Da into CPA without serum failed to improve viability of stem cells derived from human fetal liver after cryopreservation with DMSO in a range of concentrations from 2 to $10 \%$.

Polyglucinum containing 6\% of dextrans of MW 50,000-70,000 Da is also used for reduction of the volume of human UCB. Makashova et al. [111] have reported that dextrans in the concentration of $3 \%$ obtained after mixing of UCB with polyglucinum in the ratio $1: 1(\mathrm{v} / \mathrm{v})$ is suitable both for collection and cryopreservation of nucleated cells. Cord blood nucleated cell concentrates containing 3\% dextran were supplemented with DMSO in the range of concentration from 2.5 to $10 \%$ and cryopreserved using controlled rate freezing. Post thaw viability of CD $45^{+}$ cells did not differ in samples cryopreserved with the combination of 5\%, 7.5\% and 10\% DMSO. Although this study did not compare post-thaw viability after cryopreservation with DMSO alone, the data indirectly demonstrate ability of dextran to reduce DMSO concentration in cryopreservation of hematopoietic cells.

In biomedical practice including cryobiological projects, synthetic high molecular weight polymers are widely used. These polymers demonstrate excellent biocompatibility, and are biodurable materials, because cells of animal and human tissues have no correspondent metabolizing enzymes and their biodegradation or resorption occurs by reticuloendothelial system. Among such agents, polyethylene glycol (PEG), methylcellulose (MC) and polyvinylpyrrolidone (PVP) are the most commonly used as nonpermeable cryoprotectants.

PEG is a polymer of ethylene glycol readily available in a wide range of molecular weights. It is nontoxic and has been applied in biomedical research as drug-delivery system, tissue engineering scaffolds, etc. PEG has been also included in solutions for hypothermic storage of kidney and liver [112,113]. There were several studies describing cryopreservation of red blood cells [114], pancreatic islets [115,116] and vein grafts with PEG alone [117]. However, more often it has been used in mixture with permeable CPAs, mostly DMSO to reduce its toxic effect.

Petrenko [110] has studied an influence of PEG of MW 1500, 3500 and $8000 \mathrm{Da}$ in combination with different $(2 \%, 5 \%, 10 \%)$ concentrations of DMSO on viability of human fetal liver cells after slow-rate cryopreservation. It has been shown that PEG with different molecular weight increased survival of cells after cryopreservation included three-step programmable freezing protocol $\left(1^{\circ} \mathrm{C} / \mathrm{min}\right.$ down to $-40^{\circ} \mathrm{C}, 10^{\circ} \mathrm{C} / \mathrm{min}$ down to $-80^{\circ} \mathrm{C}$ and storage in 
liquid nitrogen). Survival rate determined after rapid thawing and washing out of CPAs increased with enhancement of molecular weight of PEG. The highest values for survival rates were obtained after cryopreservation of human fetal liver cells in CPA containing 6\% PEG of MW 8000 Da in combination with DMSO. Supplementation of CPA with the PEG provided a high cell viability which enabled reduction of DMSO to $2 \%$ concentration.

Yang et al. [118] compared the effects of PEG and trehalose in CPA with a reduced concentration of DMSO on slow-freezing cryopreservation of bone marrow derived MSCs from mice, rats and calves. It has been shown that DMSO could be partially replaced by PEG and/or trehalose for MSCs cryopreservation from all three species. However, the post-thaw viability, metabolic activities, proliferative capacity and differentiation potential varied among the different species. CPA containing 2\% PEG, 3\% trehalose and 2\% BSA in the combination with reduced to $5 \%$ concentration of DMSO demonstrated satisfactory values of viabilities and metabolic activities. In another study [119] these authors have shown the ability of PEG to reduce DMSO concentration for cryopreservation of human bone marrow-derived MSCs. The post-thawing viability of cells cryopreserved in CPA containing 7.5\% DMSO, 2.5\% PEG and 2\% BSA was comparable with that obtained in conventional cryopreservation in CPA included $10 \%$ DMSO $(82.9 \pm 4.3 \%$ and $82.7 \pm 3.7 \%$, respectively). MSCs cryopreserved with reduced DMSO concentration were able to differentiate toward osteogenic, adipogenic and chondrogenic lineages. Unfortunately, the molecular weight of PEG in these reports has not been indicated. In the study [119] addition of 5 or $10 \%$ PEG of MW 8000 Da to CPA failed to reduce DMSO concentration in CPA after conventional slow-freezing cryopreservation of stallion germ cells, but gave better results than DMSO alone. At supplementation of CPA, containing $10 \%$ DMSO, enhanced viability of germ cells from post-pubertal stallions. Similarly, addition of 2.5\% PEG with MW 1000 Da to CPA containing 10\% DMSO and 10\% FBS has significantly improved postthaw recovery rate, culture potential and stem cell activity in cryopreservation of mouse testis cells enriched for spermatogonial stem cells [120]. In the frame of the current review it would be of interest to evaluate the ability of PEG to reduce DMSO concentration; however, it has not been done in currently available studies.

Methylcellulose (MC) is a macromolecular polymer that has been successfully used as a supplement in a serumfree cell cultures [121]. In such cultures, it has been shown that MC can replace animal serum in the standard CPA containing $10 \%$ FBS $[122,123]$. These data demonstrate that MC can be considered as an alternative to FBS in the cryopreservation of cells for their following clinical use. Thirumala et al. [124] have used methylcellulose either alone or in combination with reduced levels of DMSO for cryopreservation of short-term expanded (Passage 1) adult human adipose tissue derived stromal cells. It has been indicated that MC alone did not provide the protection of stromal cells after conventional slow-freezing cryopreservation protocol. After thawing high levels of necrotic and apoptotic cells have been observed. At the same time 1\% MC produced similar satisfactory results with DMSO in the concentrations of 2, 4, 6, 8 or 10\%. After cryopreservation in CPA containing the combination MC and reduced as low as $2 \%$ concentration of DMSO cells demonstrated high viability, low percentage of apoptotic cells and maintained their adipogenic and osteogenic potential.

PVP is a water soluble synthetic high molecular weight polymer, which has many desirable properties including low toxicity, chemical stability and good biocompatibility. Due to these properties, PVP has been used in biomedical applications such as binders in pharmaceutical tablets, hydrogels for wound dressings, disinfectants and as a blood plasma substitute. It has been reported that PVP with an average molecular weight of 40,000 can be used as alternative to permeable CPAs as DMSO for conventional slow-freezing cryopreservation of human adipose tissuederived MSCs [125] and isolated rat islets [116]. Comparison of PVP and DMSO at concentrations of 10\% after cryopreservation in CPA supplemented with 10\% FBS using controlled rate freezing protocol has been studied on human Wharton's jelly-derived MSCs [126]. Although DMSO demonstrated a 20\% higher post-thaw cell viability, after recovery in culture MSCs cryopreserved with both DMSO and PVP the cells maintained their morphological, immunophenotypic and differentiation characteristics. Poorer cryoprotective efficiency of $10 \%$ PVP compared with $10 \%$ DMSO has been also shown on human stromal vascular fraction of adipose tissue [127]. The combination of PVP and DMSO was tested for slow cooling cryopreservation of hepatocytes. Such combinations did not offer any advantage over DMSO alone for the cryopreservation of rat hepatocytes [128]. Gómez-Lechón et al. [129] reported that freshly isolated rat and dog hepatocytes, cryopreserved in CPA containing 10\% DMSO and 2.3\% PVP showed similar viability but significantly higher recovery (cell attachment to the plates and monolayer formation) than those frozen in CPA containing DMSO alone. Hepatocytes cryopreserved in CPA containing DMSO and mixture of DMSO and PVP similarly maintained their capacity of response to P450 inducers and drug-metabolizing activity. Thus, although there are no direct literature data that the supplementation of CPA with PVP reduces effective dose 
Table 2. High molecular weight macromolecules able to reduce dimethyl sulfoxide concentration.

\begin{tabular}{|c|c|c|c|c|c|}
\hline Agent & Cell type & $\begin{array}{l}\text { Reduced DMSO } \\
\text { concentration }\end{array}$ & Additional substitutes & Tests (activity, function) & Ref \\
\hline FBS $95 \%$ & Equine MSCs & $5 \%$ & No & $\begin{array}{l}\text { Viability, morphology, growth and } \\
\text { capacity to multilineage differentiation }\end{array}$ & {$[85$} \\
\hline FBS $20 \%, 70 \%$ & Human fetal liver HSPCS & $5 \%$ & No & Viability, CFU recovery & {$[84]$} \\
\hline Sericin $1 \%$ & Rat pancreatic islets & $7 \%$ & $0.1 \mathrm{M}$ trehalose & $\begin{array}{l}\text { Survival, insulin secretion, blood glucose } \\
\text { control and renal subcapsular } \\
\text { engraftment }\end{array}$ & [91] \\
\hline $2-5 \%$ HES & Rat MSCs & $5-8 \%$ & No & Viability, differentiation capacity & {$[102]$} \\
\hline $5 \%$ HES & $\begin{array}{l}\text { Fibroblasts and } \\
\text { keratinocytes }\end{array}$ & $5 \%$ & $90 \% \mathrm{FBS}$ & $\begin{array}{l}\text { Viability, maintenance of nuclei, actin } \\
\text { and mitochondria markers }\end{array}$ & {$[103,132$} \\
\hline $6 \%$ HES & Human BM-HSCs & $5 \%$ & $4 \% B S A$ & Survival, CFU recovery & {$[105$} \\
\hline $6 \%$ HES & Canine-HSCs & $5 \%$ & $4 \% \mathrm{BSA}$ & Survival, CFU recovery & {$[106$} \\
\hline $6 \%$ HES (Pentastarch) & Human UCB-HSCs & $5 \%$ & $25 \%$ human albumin & $\begin{array}{l}\text { Survival, CFU recovery, engraftment in } \\
\text { SCID mice }\end{array}$ & {$[107]$} \\
\hline $6 \%$ HES & Human PB-HSCs & $5 \%$ & $4 \%$ human serum albumin & Viability of $\mathrm{CD} 34^{+}$cells, engraftment & {$[108$} \\
\hline $9 \%$ dextran (MW $70 \mathrm{kDa})$ & $\begin{array}{l}\text { Chinese hamster ovary } \\
\text { cells }\end{array}$ & $1 \%$ & $10 \%$ fetal calf serum & Survival & {$[109]$} \\
\hline $\begin{array}{l}3 \% \text { dextran (MW 50-70 } \\
\mathrm{kDa} \text { ) }\end{array}$ & $\begin{array}{l}\text { Human UCB nucleated } \\
\text { cells }\end{array}$ & $5 \%$ & No & Viability of $\mathrm{CD} 45^{+}$cells & {$[111]$} \\
\hline 6\% PEG (MW $8000 \mathrm{Da})$ & Human fetal liver HSPCs & $2 \%$ & No & Survival rates & {$[110]$} \\
\hline 2\% PEG (MW - NI) & $\begin{array}{l}\text { Mice, rats and calves } \\
\text { BM-MSCs }\end{array}$ & $5 \%$ & $3 \%$ trehalose and $2 \%$ BSA & $\begin{array}{l}\text { Viability, proliferation and } \\
\text { differentiation }\end{array}$ & {$[118$} \\
\hline $2.5 \%$ PEG (MW - NI) & Human BM-MSCs & $7.5 \%$ & $2 \% \mathrm{BSA}$ & Viability, differentiation & {$[119$} \\
\hline $1 \% \mathrm{MC}$ & Human AT-MSCs & $2 \%$ & No & Viability, differentiation & [127] \\
\hline
\end{tabular}

of DMSO, the mixture of PVP and DMSO manifests additive or synergistic enhancement of cell viability and function after cryopreservation.

As nonpermeable high molecular weight cryoprotectants special mention should be given to polyampholytes. Matsumura et al. [130,131] have reported that carboxylated poly-l-lysine of MW about $5000 \mathrm{Da}$ at a concentration of $7.5 \%$ without any additional substitutes was as efficient for cryopreservation of multiple cell types as $10 \%$ of DMSO. The authors assume that cryoprotective mechanism of carboxylated poly-l-lysine differs from high molecular weight polymers and caused by membrane protection similar to antifreeze proteins.

Studies where supplementation of CPA with high molecular weight molecules resulted in reduction of DMSO concentration are summarized in the Table 2. Unfortunately, it is difficult to compare ability of different macromolecules to reduce DMSO concentration, because they were done on different cell types using different cryopreservation protocols. In many studies, additional substances such as trehalose, albumin or serum have also been used. The effect of the individual substances is difficult to assess. Anyway, these studies demonstrate that cryopreservation of different cell types using a mixture of DMSO and high molecular weight agents allows the reduction DMSO concentration resulted in avoiding it toxicity with simultaneous improvement of cell viability.

\section{Removing DMSO from the cryopreserved cell-based grafts \& preparations}

In this section, we will discuss the current technologies for the removal of DMSO using the example of cryopreserved grafts, with the specific focus on clinical practices.

The common strategy of DMSO removal includes the gradual step-wise dilution of the cryoprotective agentcontaining cell suspension with washing solution, at a rate that ensures the maintenance of cells within their osmotic tolerance limits, and thus, avoiding the extensive cell swelling [133,134]. For this approach, several parameters should be considered and adjusted in each specific case. The volume of the sample, concentration and osmolarity of the CPA solution applied during cryopreservation, the temperature of the cell preparation and finally the cell type are the most critical factors occurring during CPA removal. Considering these factors, it is possible to generate an optimized protocol for CPA removal by combining the washing solution(s) composition, addition/equilibration rate and the number of dilution steps needed to reach the best result. The composition of washing solution 
would partly determine the overall rate of CPA removal. The larger the difference between osmolarities of washing and CPA solution, the slower the dilution rate used to maintain cells within osmotic tolerance limits. The supplementation of the washing solution with nonpermeable compounds (usually sugars) in quantities almost reaching the concentration of permeable CPA can moderate the influx of water into the cells and control the overall osmotic cell swelling [134]. After the washing medium is added, the cells are concentrated by centrifugation to remove the remaining CPA from the thawed sample, although that in turn, results in the additional stresses and damaging factors, associated with physical forces applied on the sensitized cells. Therefore, the development of the ideal protocol of CPA removal is challenging and requires good scientific understanding of many variables. Using mathematical modeling or computer simulation, significant efforts have been made to predict the outcomes and propose the best CPA addition/removal protocols for the specific applications $[12,135,136]$. However, our lack of ability to develop a unified protocol, due to the diversities in cellular characteristics, as well as the absence of easy to reach information sources (such as pre-adjusted software or open access on-line resources) to provide nonexpert researcher with the best options for the specific cell type, slow down the implementation of simulated data into routine cryopreservation practice.

The removal of DMSO in current clinical cryopreservation methods and banking of cell-based grafts is even more challenging, since additional highly regulated factors are introduced into the processing pipeline, but these are important to ensure patient safety and reproducibly effective application of the procedure. These issues have triggered the following multidisciplinary studies aimed to provide efficient options, combining cell biology/cryobiology and engineering approaches.

\section{Removal of DMSO from cryopreserved hematopoietic stem cell grafts}

The high clinical demand for hematopoietic stem cell transplants has driven the research toward the development of safe and efficient cryopreservation and cryobanking protocols for HSC grafts. In the majority of cases, the cryopreservation of HSC for clinical application is made under protection of $10 \%$ DMSO $[36,137]$ that brings the problem of DMSO toxicity and optimization of the DMSO removal process to the forefront as a key issue to be resolved for sample processing.

Going back to the common steps of DMSO removal process, briefly discussed before, it is necessary to highlight at least several factors, which are critical in the case of clinical HSC processing.

1. Volume - typically a range of $25-100 \mathrm{ml}$ of cryopreserved HSC graft is prepared in sealed cryogenic bags that require optimized protocols for DMSO removal. On the one hand, the rate of the dilution should be controlled to maintain the osmolarity of the total solution within the osmotic tolerance limits of processed cells, but on the other hand, it has to be fast enough to avoid the prolonged exposure of cells to the toxic DMSO.

2. Washing solution - research processes for DMSO removal, give the researcher wide flexibility in choosing the washing media components, however, the processing of cells for clinical use is more rigorous and consequently the choice is usually limited by the availability of suitable products that are currently registered pharmacopeia products permitted for direct infusion into a patient.

3. Closed environment - since the DMSO removal is considered as an additional open manipulation, the procedure of washing should be done either in the laboratory (i.e., clean room facilities suitable for GMP manufacturing) or prepared in closed systems, preserving sterility and thus, high safety of cell-based preparations.

4. Reproducibility and automation can be considered as a fourth major task in clinical DMSO removal.

\section{Manual methods of DMSO removal based on dilution/centrifugation approach}

The current standard methods for the DMSO removal from the cryopreserved HSC are based on the protocol proposed in 1995 by Rubinstein and colleagues from the New York Blood Center [138]. With or without small modifications, this method comprises two-step dilution of each stem cell unit (donor cell preparation with washing solution followed by centrifugation $[133,139]$. The precise step-by-step procedures of the current clinical-standard DMSO washing from HSC grafts are freely available from the FDA-approved product database (www.fda.gov). DMSO removal by washout methods has also been shown to improve viable recovery of cord blood cells [140]. Analyzing the information from different UCB banks, the common procedure of DMSO removal contains several steps, each at $4-10^{\circ} \mathrm{C}$ shown below:

- preparation of washing solutions in Luer-Lok syringes or washing bags; 
- establishment of the closed system by connecting several bags/syringes by tubing and Luer-Lok connectors and clamps;

- unsealing and connecting the unit to the established closed system;

- first-step dilution of the unit with washing solution $(5-25 \mathrm{ml})$ and transferring the unit into transfer/washing/transplant bag, using the established tubing;

- second-step dilution of the unit with larger volume of the washing solution;

- centrifugation at $400-880 \times g$ for $10-20$ min at $4^{\circ} \mathrm{C}$;

- adjustment of the transplant volume using the washing solution or supernatant.

The compositions of the washing solution may vary in different institutions, but generally is limited to the mixtures of saline/electrolyte media $\left(0.9 \% \mathrm{NaCl}\right.$, Lactated Ringer's, Normosol- $\mathrm{R}^{\circledR}$, Plasma-Lyte $148^{\circledR}$ or similar) with dextran-40 (5-10\%), human serum albumin (1-5\%) or HES (3-6\%), Tetraspan ${ }^{\circledR}$ Volulyte ${ }^{\circledR}$ ) or acid citrate dextrose anticoagulant [141-146].

Although the described procedure is considered as the standard, it is a very time- and labor-consuming process, which needs the involvement of trained personnel and special facilities assuring sterility of the graft. Moreover, the dilution process of the DMSO-containing grafts is not well controlled, since it is manual and affected by human factors and can result in lack of reproducibility. This drives the need of the development of automatic devices, providing a controlled, reproducible environment during the washing procedure.

\section{Device assisted methods for DMSO removal based on dilution/centrifugation approach}

Several devices have been proposed for automation of the centrifugation-based removal of cryoprotectant from cryopreserved hematopoietic grafts. The COBE ${ }^{\circledR} 2991$ Cell Processor (Terumo BCT, Inc.) represents one of the solutions for fast automatic processing of blood or bone marrow units [139,142]. The key feature of the COBE 2991 cell processor is the presence of a flexible diaphragm. When the centrifuge is spinning, the flexible diaphragm located inside the centrifuge bowl, can be inflated with hydraulic fluid. As the flexible diaphragm inflates, it presses against the bottom of the cell processing bag. This gives the COBE 2991 cell processor the ability to express fluids and/or cells for removal or collection during centrifugation. Sepax S-100 ${ }^{\circledR}$ (or Sepax 2 S-100), available from Biosafe $S A^{\circledR}$, GE Healthcare represents another option of automatic processing of hematopoietic grafts, including umbilical and peripheral blood or bone marrow $[143,144]$. The technology relies on the use of a separation chamber that provides both separation through rotation of the syringe chamber (centrifugation) and component transfer through displacement of the syringe piston. In both cases, manufacturers provide the possibility to prepare the washing procedure in a closed environment, significantly reducing the risks of contamination. Abonnenc et al., showed that the Sepax-2 assisted washing of autologous HSC grafts resulted in 95\% removal of DMSO (used as $10 \%)$ and post-wash viable $\mathrm{CD} 34^{+}$cell recovery of around $80 \%[147]$.

\section{Device-assisted methods of DMSO removal based on dilution/filtration approach}

Another technologically different approach for CPA removal from the cryopreserved grafts is based on the filtration/dilution technique. The pioneering automation using this approach is based on the development of the spinning bowl for deglycerolizing of red blood cells, where cells initially sediment to the periphery of the bowl and the diluting solution is slowly introduced at the periphery $[133,148]$. Further progress in utilizing this technique resulted in the development of Haemonetics ACP215 Automated Cell Processor ${ }^{\circledR}$ (Haemonetics Corporation). However, this device is mainly employed for glycerolization and deglycerolization of red blood cell units and little is known about the use of this device for DMSO removal. Starting from the early 2000s several reports have been presented on the use of CytoMate ${ }^{\circledR}$ (Baxter/Nexell) closed fluid management system for automatic washing of hematopoietic transplants. Calmels et al. showed that the removal of DMSO from cryopreserved HSC grafts was associated with limited loss of CD34+ cells, while $96 \%$ of DMSO was eliminated [149]. The successful application of this device was also confirmed for umbilical cord blood units [150] and peripheral blood products [151,152]. The authors showed that the degree of removal of DMSO is very high and therefore might ameliorate the transfusionrelated side effects of cryopreserved HSC transplants. Recently, the new Lovo ${ }^{\circledR}$ filtration-based device has been launched by Fresenius Kabi for automatic washing and volume reduction of white blood cells [153]. Authors indicate that the Lovo device is an advantageous option for efficient washing and enriching of more than one thawed HSC graft simultaneously. The two- or three-cycle washing resulted in 96-98\% elimination of DMSO and around 80\% viable $\mathrm{CD} 34^{+}$cell recovery from the cryopreserved peripheral blood HSC grafts [153]. 
Although, the presented automation solutions can significantly improve the reproducibility of processing of clinical HSC grafts, the high cost of these devices determines their adoption by large transfusion centers with high numbers of routine clinical applications of HSC transplantations. Adaptation of a hollow fiber dialysis approach for CPA removal can represent an alternative cost-efficient option for the controlled and safe washing of DMSO from cryopreserved tissue products [154,155], however, the more wide-spread use of this method is limited by the large volumes of the processed samples and requires adaptation for smaller size tissue products.

\section{Removal of DMSO from small volume cell-based \& tissue-engineered grafts}

In the previous sections, we have reviewed the possibilities of clinical-grade DMSO removal from large-volume HSC grafts. However, currently the field of regenerative medicine has stepped far beyond HSC transplantation toward the development of effective treatments for nonhematopoietic disorders, specifying so-called multipotent MSCs as the most frequently applied cell type [155]. The accurate nomenclature and biological identity of these cell preparations is the subject of current debate and any differences within this cell type in response to DMSO is not yet clear $[52,156,157]$.

The common practice of nonsystemic local administration of MSCs includes the application of more than $0.5 \times 10^{6}$ cells per $\mathrm{kg}$ of bodyweight in a limited volume of vehicle solution. In this case, the final administration dose can comprise up to $10^{8}$ cells in only a few milliliters of the solution $(<10 \mathrm{ml})$. Cryopreservation may represent the only choice to provide fast availability of cellular graft for application as well as assure the safety and quality of the product in repeatable application. However, the presence of high concentrations of DMSO in the vehicle solution may negatively act locally on the patient's cells and tissue within the site of injection as discussed above. For example, Galvao et al. showed that the DMSO induces retinal apoptosis in vivo at low concentrations (>1\%) [17]. In an in vitro rat hippocampal culture preparation, DMSO produced neuronal loss at concentrations of 0.5 and $1.0 \%$ [18] and other reports are explained in Section 1. These reports confirm the need for reducing DMSO concentration in cryoprotective medium, especially when the cellular product is supposed to be used for the restoration of neural tissue. Moreover, safety guidance remains similar to large volume grafts (e.g., HSC transplants). Thus, the development of controllable engineering approaches of DMSO removal from the small volume cryopreserved grafts seems highly desirable to achieve the necessary therapeutic outcomes and minimize vehicle solution-associated side effects.

Recently, Tostoes et al. demonstrated the use of a novel filtration system for the removal of DMSO from cryopreserved small volume samples, containing $10^{7}$ fetal lung fibroblasts or bone marrow MSCs [158]. The system resulted in the elimination of $85-95 \%$ of DMSO with more than $70 \%$ cell recovery. Memon et al. introduced the device for controllable extraction of DMSO from the frozen-thawed samples, based on sandwich structure, composed of two channels, separated by polytetrafluoroethylene (PTFE) membrane and syringe pumps [159].

Microfluidic devices have emerged as a promising technology for manipulating cell populations in small scaled microchannel systems [160]. The removal of CPA in such devices is achieved mainly through diffusion, reducing osmotic stresses and thus, damaging factors, which may occur in cells subjected to other techniques [161]. Moreover, microfluidics systems provide the user with highest degree of process control and reproducibility, which are important aspects of clinical processing of cell-based grafts. Park et al. applied an electro-wetting-on-dielectricbased microfluidic platform to screen DMSO mixtures on cell toxicity and cryoprotection efficiency [162]. Song et al. applied a microfluidic device to control loading and unloading of CPA by diffusion and laminar flow [160]. The group of Hubel also studied in some depth, the possibilities of using microfluidic devices based on diffusionbased extraction of DMSO from cell suspensions $[161,163,164]$. Starting from a two-channel flow system, where the DMSO-containing cell suspension is simultaneously flowing in parallel with the washing solution [163], the process has been optimized by introducing either several stage devices [164] or three-channel systems [161]. As a result, more than $95 \%$ of DMSO extraction can be achieved, while preserving the viability of cells. Authors assumed, that the transport of CPA from the cell-laden stream to the wash streams occurs solely by cross-stream diffusion, driven by the concentration gradient [161].

The administration of stem cells within biomaterial scaffolds may provide several advantages over the classical cell therapy in particular applications. 3D organization, more physiological elastic properties and cell-cell, cellmatrix interactions provide additional cell support and enhance the survival and therapeutic properties of stem cells in localized delivery. To provide wide availability of tissue-engineered grafts for further applications, efficient cryopreservation protocols are needed, including the efficient loading of CPA into 3D construct, finding the optimal freezing and thawing protocols and finally washing off the CPA from the thawed sample. In this case unusually, the 
cell-cell and cell-matrix interactions may negatively affect cell viability and function after cryopreservation [165-167]. It has been shown that cells attached to gelatin- and Matrigel-based substrates can largely survive cryopreservation, although the cell viability of adherent MSCs is significantly lower (up to $35 \%$ ) than that in suspension $[165,166]$. There are several reports on the cryopreservation of 3D tissue-engineered grafts, employing DMSO as a cryoprotectant [167172]. However, the analysis of the functional properties of cryopreserved grafts has been currently limited to the in vitro studies. The DMSO unloading is usually prepared in static conditions (diffusion), by continuous changes of the CPA with washing solution (usually culture medium) $[168,170]$. In turn, the clinical cryobanking of tissue-engineered grafts would likely bring similar challenges, presented for cell-based transplants and thus, the development of reliable, automation devices, assuring reproducible cryopreservation outcomes and avoiding the possible toxicity associated with DMSO residues is an important aspect. Recently, several reports have shown the application of bioreactor-based devices for cryopreservation of MSCs within 3D scaffolds $[167,169]$. The application of oscillating perfusion systems for the controlled loading and unloading of DMSO resulted in a significant increase in MSC recovery within collagen scaffolds [169]. Applying a microfluidic bioreactor system Bissoyi et al. concluded that MSCs attached to a particular substrate can be effectively cryopreserved, if subjected to lower shear stress [167]. Altogether, the precise control over the environment could assist in the establishment of standardized cryopreservation protocols for complex tissue-engineered grafts for clinical applications.

\section{Concluding remarks on post-thaw DMSO dilution to reduce negative effects}

Much effort has been made toward the development of safe and reproducible systems and protocols of DMSO removal from the cryopreserved grafts in clinical scale, especially in the field of HSC transplantation. However, it remains the case, that DMSO elimination is not provided in the majority of HSC transplants [137] associated with negative effects. Therefore, the development of low-cost, automatic devices to remove DMSO, assuring minimal contamination probability and high control and reproducibility of the process may be considered critical in translating stem cell/tissue engineering research into a wider range of clinical practice.

\section{Alternatives to DMSO}

In recent years, the concept that it will be possible to replace DMSO in cryopreservation media while still maintaining good post-thaw recoveries has been discussed [173]. However, a wide application for such an approach has yet to be achieved. This section gives an objective assessment of the current status for this approach.

\section{Theoretical alternatives based on equivalent mechanism of action}

In the following, we discuss the potential substitution of the specific mechanisms that have been attributed to DMSO in generating a cryoprotective effect.

Perhaps the most significant aspect of DMSO-related cryoprotectant activity is linked to its capability to enter cells easily both through osmosis and potentially via aquaporin 3-independent channel diffusion [174]. One consequence of this is intracellular water displacement, which is a putative cryoprotective mechanism limiting intracellular ice crystal formation. Water displacement with limited osmotic stresses is also associated with other 'penetrating' cryoprotectants such as sugar alcohols (e.g., ethylene glycol, propylene glycol, glycerol) and other compounds. Although findings differ significantly for different cell types, in general terms, DMSO seems to exhibit the lowest membrane permeability coefficient times off all established penetrating cryoprotectants, with the possible exception of glycerol [175].

In connection with its ability to transition membranes, DMSO has further modulating effects on cell membrane permeability. In contrast to other cryoprotectants, DMSO is unique in dehydrating the phospholipid headgroups while raising the membrane phase transition temperature [176]. Even the quickly permeating glycerol seems to exert a very different hydrogen-bonding capability by increasing the repulsive forces between bilayers [177].

In turn, much of the damage related to cryopreservation is linked to membrane integrity. DMSO reduces membrane rigidity and, at high concentrations, induces pore formation, a mechanism presumed to contribute to reduction of mechanical and osmotic stresses during cryo-related cellular swelling and shrinking, tissue perturbation and ice formation [178]. To modulate membrane rigidity by other means, the amount of unsaturated fatty acids can be altered in pre-treatment [174] or lipid molecules can be added to the cryo-protective solution [179] (although the unique action of DMSO on lipid bilayers, for example on liposomes, needs to be considered in comparative studies) [180]. To induce membrane transition channels or pores, transfection agents like polyethylene glycol and 
PVP have sometimes been added to cryo-protective solutions and have proven effective in comparison with DMSO [181-183].

Other chilling injuries have been attributed to lipid peroxidation and protein denaturation. Some antioxidant properties have been attributed to DMSO itself [184,185], specifically its reaction with hydroxyl radicals, producing methyl radicals, in turn producing ethane, and also undercutting the formation of carbonyl groups [186]. Addition of a wide variety of antioxidants has been attempted in the formulation of cryoprotectant solutions including mitragynine, glutathione, curcumin $[187,188]$ including natural compounds [189] and mitochondria-targeted antioxidants [190,191]. It has been observed that other antioxidants may have at least equivalent antioxidative potency compared with DMSO [29]. However, in the specific pursuit of a cryoprotectant solution that emulates the molecular interactions of DMSO as closely as possible, it should be borne in mind that some of these alternatives (e.g., vitamin E) $[192,193]$ are not known as particular scavengers of hydroxyl radicals.

Further innovations that have been considered in counteracting the results of oxidative damage and other cryoinjuries include the use of apoptosis inhibitors [194], with a caspase I inhibitor having been adopted into a commercially available medium (CryoStor CS5N - STEMCELL Technologies), and the use of anti-freeze proteins (AFP) as a DMSO alternative [195]. Incorporating AFP qualities into polymer design has shown some promise [196]; although cryoprotectant success with polymers goes well beyond the emulation of AFP macroscopic properties. Nonpenetrating polymers of high molecular weight have long been investigated, not for their capability to replace DMSO, but to supplement cryoprotection from the extracellular vantage point, by inhibiting ice crystallization and reducing mechanical damage. For example, for HES, a 6\% admixture with 5\% DMSO was generally favored for partially historical reasons [102]. Other polymers derived from natural compounds include gelatin, chitosan or alginate, all in themselves employed as an addition to, not a substitute for DMSO. However, as more recently developed polymers have entered the field and it has been suggested that they are a viable substitute for DMSO as discussed in Section 4 and in the following section.

\section{Known DMSO-free solutions}

In the preceding section, we have discussed the theoretical considerations and challenges of replacing DMSO with other compounds mainly from the perspective of the putative mechanism of action of DMSO as a cryoprotectant.

However, it may be that for any given purpose the specific effects of DMSO are not deemed pertinent or important enough to attempt their emulation. Replacement strategies may instead begin by first looking at evidence whether the alternative is at least as effective as DMSO.

Table 3 lists such examples of 'successful' DMSO-free cryopreservation, irrespective of whether these were aimed at addressing specific mechanisms of action. In consideration are only those studies that compared a DMSO-free cryo-protective solution directly to a DMSO-containing solution. Not included are studies that aimed at a reduction rather than total elimination of DMSO, or studies where the efficacy of the proposed cryo-protective solution was not experimentally compared with a DMSO-containing solution. Table 3 also excludes the various alternative solutions advanced only for gametes - it is a long-established tenet of the field that results on cryoprotectant efficacy and toxicity vary greatly between different cell types and situations, but we can at least summarize that for a variety of cells which are relevant in regenerative medicine and tissue engineering DMSO-free cryoprotection has been demonstrated using a number of cryo-protective solutions from 'traditional and basic' CPAs like glycerol, to different sugar combinations and novel polymer gels. Equivalence or superiority was established by a variety of assays, but often not going much beyond cell survival (which is not always the most conclusive measure) [102]. Further analysis of such solutions will be required in the context of advanced development. However, the ability to fully assess DMSO-free solutions depends on understanding their chemical compositions. As indicated in Table 4, a range of DMSO-free CPA are now commercially available, but solution composition is frequently subject to proprietary information.

\section{Commercial development \& regulatory considerations}

Commercial preparations of DMSO containing cryoprotectants are now widely available and in use for final product formulation in more than 20 cell therapy clinical studies and trials (e.g., NCT00672542 [205], NCT02467387 [206], NCT02166177 [207], NCT01671072 [208], NCT02500849 [209], NCT02208362 [210], NCT02028455 [211], NCT02387723 [212], NCT0212988 [213], (Personal Communication from manufacturers and suppliers of CryStor ${ }^{\circledR}$ [Biolife, STEMCELL Technologies] and CellBanker ${ }^{\circledR}$ [Zenoaq, ASMBio]). However, improved cryoprotectant solutions are urgently needed, in part to address the ever-increasing complexity and di- 
Table 3. Reported successful comparisons of 'dimethyl sulfoxide-free' cryopreservation solutions with dimethyl

\section{sulfoxide-based cryoprotective solutions.}

\begin{tabular}{|c|c|c|c|c|c|}
\hline DMSO-free CPA composition & DMSO as sole CPA & $\begin{array}{l}\text { Additives present in both } \\
\text { DMSO-free and DMSO } \\
\text { CPAs }\end{array}$ & Assay & Cell type & Ref. \\
\hline FCS $+0.5 \mathrm{M}$ sucrose $+20 \%$ glycerol & $10 \%$ & $\begin{array}{l}\text { No carrier solution } \\
\text { information }\end{array}$ & Cell survival & $\begin{array}{l}\text { Human umbilical cord } \\
\text { tissue }\end{array}$ & [197] \\
\hline $7.5 \%$ PLL, $5 \%$ ectoin, $5 \%$ dextran & $10 \%$ & DMEM (?) & $\begin{array}{l}\text { - Cell survival } \\
\text { - Apoptosis } \\
\text { - Proliferation }\end{array}$ & NK cells & [173] \\
\hline $\begin{array}{l}\text { 1) } 300 \mathrm{mM} \text { trehalose, } 10 \% \text { glycerol, } \\
0.01 \% \text { ectoin } \\
\text { 2) } 300 \mathrm{mM} \text { ethylene glycol, } 1 \mathrm{mM} \\
\text { taurine, } 1 \% \text { ectoin }\end{array}$ & $10 \%$ & Normasol- $\mathrm{R}^{\mathrm{TM}}$ & $\begin{array}{l}\text { - Cell attachment } \\
\text { - Differentiation }\end{array}$ & $\begin{array}{l}\text { Jurkat cells } \\
\text { MSC }\end{array}$ & [198] \\
\hline $32 \%$ Pentaisomaltose & $20 \%$ & $\begin{array}{l}4 \% \text { human serum } \\
\text { albumin, } 2 \mathrm{IE} / \mathrm{ml} \text { heparin } \\
\text { carrier solution (?) }\end{array}$ & $\begin{array}{l}\text { - Cell survival } \\
\text { - Colony growth } \\
\text { - Engraftment }\end{array}$ & $\mathrm{HSC}$ & [199] \\
\hline $20 \%$ Trehalose & $20 \%$ & $10 \%$ FBS, RPMI- 1640 & Cell survival & GLC-82 & [200] \\
\hline $6,8,10 \%$ I-carnitine & $6 \%$ & $\begin{array}{l}10 \% \text { FBS, RPMI- } 1640 \\
\text { DMEM- depending on cell } \\
\text { type }\end{array}$ & $\begin{array}{l}\text { - Cell survival } \\
\text { - Proliferation }\end{array}$ & $\begin{array}{l}\text { MCF-7 } \\
\text { NIH-3T3 }\end{array}$ & [200] \\
\hline $\begin{array}{l}\text { 1) } 10 \% \text { PVP40, } \\
\text { 2) } 0.05 \mathrm{M} \text { glucose, } 0.05 \mathrm{M} \text { sucrose, } 1.5 \mathrm{M} \\
\text { ethylene glycol }\end{array}$ & $10 \%$ & $10 \%$ FBS, ADMEM & $\begin{array}{l}\text { - Apoptosis } \\
\text { - Cell survival } \\
\text { - Differentiation } \\
\text { - Phenotyping }\end{array}$ & Human MSC & [126] \\
\hline 1-10\% Betaine & $1-20 \%+$ Trehalose & $10 \%$ FBS, medium (?) & Cell survival & $\begin{array}{l}\text { Hela } \\
\text { GLC-82 } \\
\text { MCF-10 }\end{array}$ & [201] \\
\hline Nil & $10 \%$ & $\begin{array}{l}1-20 \% \text { Trehalose, } 10 \% \text { FBS, } \\
\text { medium (?) }\end{array}$ & Cell survival & $\begin{array}{l}\text { Hela } \\
\text { GLC-82 } \\
\text { MCF-10 }\end{array}$ & [201] \\
\hline $\begin{array}{l}200 \mathrm{mmol} / \mathrm{I} \text { Trehalose, } 200 \mathrm{mg} / \mathrm{l} \\
\text { cholesterol, 30\% PVP40, Lecithin }\end{array}$ & $10 \%$ & $10 \%$ serum, RPMI- 1640 & $\begin{array}{l}\text { - Morphology } \\
\text { - Apoptosis }\end{array}$ & Sheep ovar & [182] \\
\hline $5 \% \mathrm{HES}$ & $10 \%$ & $\begin{array}{l}10 \% \text { serum, } \\
\text { DMEM-medium }\end{array}$ & $\begin{array}{l}\text { - Cell survival } \\
\text { - Proliferation } \\
\text { - Differentiation }\end{array}$ & Human MSC & [102] \\
\hline $25 \% \mathrm{PLL}$ & $10 \%$ & $\begin{array}{l}10 \% \text { PVA-gelatin (ratio } \\
9: 1, \text { w:w), } \\
10 \% \text { serum, } \\
\text { HEPES-buffered } \\
\text { RPMI-medium }\end{array}$ & Cell survival & $\begin{array}{l}\text { Vascular smooth muscle } \\
\text { cells } \\
\text { Endothelial cells }\end{array}$ & [202] \\
\hline $\begin{array}{l}\text { 1) } 1 \% \text { proline, } 10 \% \text { ectoin, } \\
\text { 2) } 5 \% \text { proline, } 5 \% \text { ectoin, } \\
\text { 3) } 10 \% \text { proline, } 10 \% \text { ectoin, } \\
\text { 4) Biofreeze (Biochrom) }\end{array}$ & $10 \%$ & $1 \%$ methycellulose in PBS & $\begin{array}{l}\text { - Cell survival } \\
\text { - Differentiation }\end{array}$ & Human MSC & [203] \\
\hline $\begin{array}{l}\text { 1) } 10 \text { uM ROCK inhibitor, } \\
\text { 2) } 2.5 \% \text { PEG, } \\
\text { 3) } 10 \text { uM ROCK inhibitor, } 2.5 \% \text { PEG }\end{array}$ & $10 \%$ & $\begin{array}{l}\text { No carrier solution } \\
\text { information }\end{array}$ & $\begin{array}{l}\text { - Cell survival } \\
\text { - Colony Formation } \\
\text { - Apoptosis }\end{array}$ & hESC & [181] \\
\hline $5-20 \%$ PLL & $10 \%$ & DMEM-medium & Cell survival & L929 & [204] \\
\hline $7.5 \%$ PLL & $10 \%$ & DMEM-medium & $\begin{array}{l}\text { - Cell survival } \\
\text { - Differentiation }\end{array}$ & MSC & [204] \\
\hline
\end{tabular}

versity of cell-based products, but also other aspects of regenerative medicine including the preservation of complex tissues and organs. Publication of preservation media compositions and results in clinical trials (as in the examples above) will be crucial to promoting efficient and safe development of cell therapies. However, the main driver of the field remains the fertility sector and innovation by trial and error during in-house protocol development.

While there has long been talk in the field of employing classical drug screening, discovery and design methodologies to cryoprotectant development, these methods are still uncommon and in their infancy. Cell cryopreservation in 96-well tissue culture trays has been demonstrated for several cell types [132,174,214], but not yet scaled to 384-well plates more commonly used in high-throughput screening. Differential evolution algorithms [198] and quantitative 
Table 4. Commercially available dimethyl sulfoxide-free cryoprotective reagents, with indications of GMP status and availability for clinical application.

\begin{tabular}{|c|c|c|c|c|}
\hline Name & Company & Replacement CPA & Reported GMP status & Description \\
\hline PRIME-XV ${ }^{\circledR}$ FreezIS DMSO-Free & Irvine Scientific & Not disclosed & $\begin{array}{l}\text { 'cGMP' Drug Master File } \\
\text { registration }\end{array}$ & $\begin{array}{l}\text { - For MSC only } \\
\text { - Animal-free, } \\
\text { - Chemically defined }\end{array}$ \\
\hline FREEZEstem ${ }^{\top M}$ & BioLamina & Not disclosed & $\begin{array}{l}\text { ‘GMP-compliant' } \\
\text { ISO13485 }\end{array}$ & $\begin{array}{l}\text { - Serum free } \\
\text { - Xeno free }\end{array}$ \\
\hline $\begin{array}{l}\text { STEM-CELLBANKER }{ }^{\circledR} \text { 'GMP } \\
\text { grade' (NB DMSO free } \\
\text { 'GMP-grade' version } \\
\text { manufactured since 2015) }\end{array}$ & $\begin{array}{l}\text { Zenoaq Resource (supplier } \\
\text { Amsbio) }\end{array}$ & $\begin{array}{l}\text { 1,2-dihydroxypropane serum } \\
\text { Glucose } \\
\text { Polymer }\end{array}$ & $\begin{array}{l}\text { Drug Master File (US) } \\
\text { 'GMP-grade' }\end{array}$ & $\begin{array}{l}\text { - Chemical defined } \\
\text { - Animal free } \\
\text { - Xeno free }\end{array}$ \\
\hline ReproCryo RM & Reprocell & Not disclosed & $\begin{array}{l}\text { R\&D only (NB the DMSO free } \\
\text { version is not manufactured in } \\
\text { a GMP-compliant facility) } \\
\text { Drug Master File (JP) }\end{array}$ & $\begin{array}{l}\text { - Xeno free } \\
\text { - Chemically defined }\end{array}$ \\
\hline CryoNovo ${ }^{T M}$ P24 & Akron Biotech & Not disclosed & $\begin{array}{l}\text { R\&D only } \\
\text { Raw material to Pharmacopeia } \\
\text { (US, EP, JP) }\end{array}$ & $\begin{array}{l}\text { - Serum free } \\
\text { - Xeno free }\end{array}$ \\
\hline $\begin{array}{l}\text { CryoSOfree }^{T M} \text { DMSO-free } \\
\text { Cryopreservation Medium }\end{array}$ & Sigma & $\varepsilon$-poly-L-lysine & $R \& D$ only & $\begin{array}{l}\text { - Chemically defined } \\
\text { - Animal free }\end{array}$ \\
\hline $\begin{array}{l}\text { pZerve }{ }^{T M} \\
\text { Cryopreservation solution }\end{array}$ & Sigma & Not disclosed & R\&D only & $\begin{array}{l}\text { - Chemically defined } \\
\text { - Animal free }\end{array}$ \\
\hline CryoNovo ${ }^{T M} \times 12$ & Akron Biotech & Not disclosed & $R \& D$ only & $\begin{array}{l}\text { - Serum free } \\
\text { - Xenofree }\end{array}$ \\
\hline StemCell Keep & Funakoshi & Not disclosed & R\&D only & $\begin{array}{l}\text { - Serum free } \\
\text { - Xenofree }\end{array}$ \\
\hline CryoScarless DMSO-free & Funakoshi & Not disclosed & R\&D only & $\begin{array}{l}\text { - Protein free } \\
\text { - Serum free }\end{array}$ \\
\hline ReproCryo DMSO FreeTM & Reprocell & Not disclosed & $R \& D$ only & $\begin{array}{l}\text { - Xenofree } \\
\text { - Chemically defined }\end{array}$ \\
\hline $\begin{array}{l}\text { Ibidi Freezing Medium } \\
\text { DMSO-free }\end{array}$ & Ibidi & Not disclosed & R\&D only & - Serum free \\
\hline Biofreeze & Biochrom GmbH & Not disclosed & $R \& D$ only & $\begin{array}{l}\text { - Animal free } \\
\text { - Serum free }\end{array}$ \\
\hline Bambanker DMSO Free & Nippon Genetics & Not disclosed & R\&D only & - Serum free \\
\hline
\end{tabular}

GMP: Good manufacturing practice; R\&D: Research \& development.

structure-activity relationship (QSAR) models have been employed [174], but use of functional relationship models has not yet been widely reported.

Recently, there has been a marked influx of several novel commercial cryoprotectants, many specifically aimed at the regenerative medicine market, that are marketed 'DMSO-free' (Table 4). These products are now beginning to be used in clinical studies and trials for cell therapy. It is important to be careful in the process of qualification for such materials to ensure they are suitable for use in manufacture of products for use in humans: a label of 'GMP-grade' will not be sufficient to assure adequate quality and safety for new applications. In fact, the term 'GMP-grade' is not recognized by regulators and raw materials typically cannot be certified by a regulator as made to GMP. Any raw material publicized as 'GMP-grade' will require considerable interrogation of the supplier to establish what their statement actually means (n.b. DMSO can be manufactured as a GMP therapeutic product in its own right, it is not then necessarily intended to be used as a raw material). The construction of a dossier of information, including manufacturing processes, testing and risk assessment, is an important first step in checking the suitability of a new CPA for use in humans. Where such dossiers have already been evaluated by regulatory authorities (such as in a drug master file) this adds confidence that the CPA will be acceptable but does not necessarily preclude the need for a case-by-case evaluation for each new product. Currently, reagent suppliers are utilizing a number of approaches including CE Marking and ISO13485 compliance to demonstrate suitability, although these are more typically used for medical devices. Useful guidance has been published in the United States Pharmacopeia (USP) (USP 1043, Ancillary materials for cell, gene and tissue-engineered products) and the European Pharmacopeia (EP) 5.2.12 for raw materials of biological origin. Manufacturers will need to understand how best to utilize such approaches for their own cell therapy products. There are significant challenges on the path 
The 3Rs of DMSO toxicity elimination
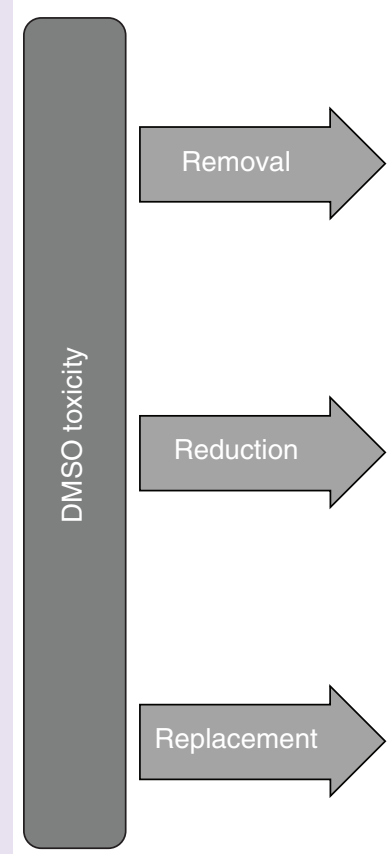

Research-application opportunities

High flexibility in choosing the methods of CPA removal (centrifugation, microfluidics, filtration)

High flexibility in choosing the composition of the diluent (any saline solution with or without supplements)
Supplementation of CPA solution compounds

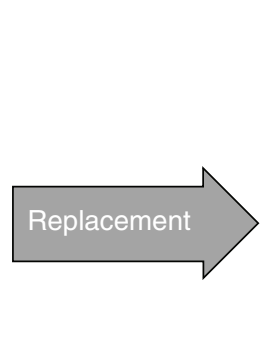

Washing out the before application

DMSO in

CPA solution by

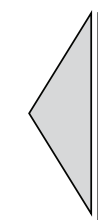
by different
Sugars (glucose, dextrose, trehalose, sucrose) Macromolecules (albumin, HES) Polymers (PEG, PVP, PLL) Antifreeze proteins and bio-compatible solutes (proline, ectoine) Antioxidants and anti-apoptotic

agents different compounds

\section{Clinical-application} challenges*

Automation (device-assisted methods)

Closed system

Materials and components suitable for manufacture of GMP products

Clinically accepted (pharmaceutical grade or medical device certified) washing solutions

Components of CPA solutions suitable for manufacture of GMP products

Validation of the manufacturing/ cryopreservation procedure (toxicity and safety studies of CPA solutions and components)

or

Figure 1. Options to consider when developing cryoprotective agent strategies to minimize concerns around including dimethyl sulfoxide as an additive. These comprise ' 3 Rs' - removal (by dilution or washout in the thawed cell product); reduction (by lowering the DMSO concentration in the CPA mixture and adding other secondary CPA such as sugars - often an achievable strategy as long as efficacy of the thawed product can be maintained); replacement (by developing CPA mixes using a range of solutes avoiding DMSO altogether which also raises questions about the efficacy of any new mixture, and whether these solutes have existing regulatory approval for human application).

*Before actual clinical application there may be extensive work on product development which will require a good understanding of the specific regulatory requirements for the final cell therapy product and the most applicable standards [215].

CPA: Cryoprotective agent; DMSO: Dimethyl sulfoxide; GMP: Good manufacturing practice; HES: Hydroxyethyl starch; PEG: Polyethylene glycol; PLL: $\varepsilon$-poly-L-lysine; PVP: Polyvinylpyrrolidone.

from research product to clinical application as outlined in Figure 1. This transition will involve considerable work on product development which will require a good understanding of the specific regulatory requirements for the final cell therapy product and the most applicable standards [215].

Such innovation is facilitated because regulatory barriers to marketing a cryoprotectant even as 'clinical grade' (n.b. This term is not recognized by regulators) are comparatively low compared with the medical products that they are aimed to preserve. From a regulatory perspective, cryopreservation is required to 'not alter the relevant biological characteristics' of tissues and cells (see below). This implies that product developers must mitigate for the challenge of incorporating cryoprotectant effects - as illustrated by the fact that in spite of decades of widespread use, DMSO is acknowledged to elicit cytotoxicity and other long-term effects on cellular behaviors and these are still being explored. The consideration that cryoprotectant-related changes to membrane integrity, epigenetics, cyto-metabolism and proteomics might affect therapeutic mechanisms of action (particularly in those cell therapies that rely on complex cellular interactivity, 'paracrine' or 'bystander' effects) is unlikely to be limited to DMSO. The current Industry practice of not disclosing the exact composition of cryo-protective solutions is a hinderance to protocol improvement and development of greater understanding of preservation of the complex and diverse cell-based products.

Recognition of the crucial effect that preservation may have on the quality and safety of cell therapy products is acknowledged and accommodated within existing regulatory considerations for manufactured biological products. These considerations have been captured as part of guidance documents dealing with consistency and comparability. 
Consistency of a product from batch to batch is crucial and would also be expected for a preservation stage within a licensed manufacturing process such as cell banking, preservation of 'intermediates' (such as preserved progenitor cells derived from the original pluripotent stem cell line) and the final product, as well as storage and transportation. Comparability is the regulatory term used for the requirement to demonstrate that when a process has changed, such as the type or composition of a CPA, the product has not been affected adversely by that change from quality and safety perspectives. The manufacturer should consider the need to demonstrate 'comparability' between the product made by the original process and the new methods/materials. Relevant information on performance of a comparability study is given in the guidance document ICH Q5E [216] which is mutually recognized in EU, US and Japanese regulation.

For consideration of both consistency batch-batch and comparability after process change, it is also important for the manufacturer to develop adequate knowledge of the cell preparations they are using and ensure use of suitable critical quality attributes [217]. This may demand multiple parameters for viability and a panel of biomarkers and functional assays for the cells involved. This will be important and expected by regulators to give confidence that the chosen bioanalytics regime will detect changes of significance for safety and efficacy of the final product.

Overall process verification requirements will have implications for how a manufacturer should assess their cryopreservation methods and is captured in document ICH Q8 [218]. More specifically, the manufacturer should also consider the composition of CPA solutions and assess the risks from additives or excipients in CPAs. These risk elements might include, in particular, those of biological origin (notably animal origin with attendant risk of viral contamination), toxic compounds, allergens, mitogens and particulates. In addition, cryovial material should be assessed for potentially harmful leachates and particle release. It is also important not to forget the potential influence of cell culture growth media components included with the CPA during cryopreservation, both in terms of their direct effect on the cells 'solutions effects' (see Mazur et al. 1972) [219] as the unfrozen solutes are concentrated around the cells, and also in terms of what chemical interactions may occur between CPA, media or cryovial components.

Cryostorage and the potential long-term exposure of cells to CPAs, is also a relevant part of manufacturing considerations reviewed by regulators. In particular, it is worth noting that EU GMP guidance now includes a new annex (Annex 15, section 6, 'Verification of transportation') which came into effect in 2015 and provides further guidance useful for cryopreserved products.

\section{General conclusion}

The use of DMSO has been important in the successful treatment of many thousands of patients worldwide with serious conditions such as leukemia, and continues to be present in drug preparations and to provide the CPA of first choice for the diverse and complex range of novel cellular therapies now being developed. However, the wide-ranging biological impact of DMSO we have described above, combined with the known adverse reactions which may occur in patients subjected to DMSO containing preparations, means that a greater selection of CPA solutions may well be in demand for the future [220]. We have described the commercially available DMSO-free reagents already on the market and in some cases, already in use in clinical trials of new cell-based medicines. The possible toxicities and impact on cell behavior will need to be investigated in different therapeutic cell types to avoid early abandonment of DMSO, only to discover unexpected adverse events arising from the premature uptake of new lesser-studied and unproven CPAs. The rapid development of novel and combination therapies means that the search for new CPA molecules will and must continue, as should careful evaluation of their biological impact in diverse cell types. Knowledge of the nature and diversity of cell populations within cell-based clinical products is vital if the results of cryopreservation investigations are to be compared and this is particularly true of the so-called 'MSC' group, which clearly represents a number of biologically different cell types that may respond differently to a particular CPA. As a generalization, concerns surrounding DMSO toxicity can also be addressed by considering the '3R's of DMSO toxicity mitigation' (Figure 1); removal (after cryopreservation); reduction (using additional secondary CPA) or replacement (using other CPA to completely avoid DMSO). These strategies should be given due consideration by anybody developing cryopreservation protocols. In particular, the current challenges being experienced by developers of combined antibody receptor (CAR) T-cell products may benefit from the use of the 'DMSO 3Rs' or alternative CPAs outlined in this review.

The development of new CPAs will require more sophisticated high-throughput screening systems and possibly establishment of model cell systems for a range of cell types as proposed by Stacey et al. [220]. However, few drugs or clinical interventions are risk free and it is highly likely, that with the availability of refined combination CPAs 
and automated DMSO removal devices, DMSO will continue for the foreseeable future, to contribute to the roll out of life saving interventions for an increasing range of cell-based medicines.

\section{Future perspective}

Over the past decade, there have been many comments recorded about possible negative implications of the use of DMSO as a cryoprotectant, and exhortations made to find replacements. We fully support continued objective research into these topics and robust audit of current cryopreservation practices where DMSO is used. However, in parallel it must be recognized that at the present time, the vast majority of applied cryopreservation practices depend upon the efficacy provided by DMSO for high functional capacities after thawing. The development of new CPAs will require more sophisticated high-throughput screening systems and possibly establishment of model cell systems for a range of cell types as proposed by Stacey et al. [220]. Many of the novel cryoprotectants appearing in research publications have not progressed to widespread uptake or regulatory approval at the current time but they will provide invaluable signposts to how to better assess both efficacy and biological impacts of all cryoprotectants (including DMSO) moving forward. However, few drugs or clinical interventions are risk free and it is highly likely, that with the availability of refined combination CPAs to lower DMSO concentrations, and automated DMSO removal devices, DMSO will continue for the foreseeable future to contribute to the roll out of life saving interventions for an increasing range of cell-based medicines, and improved cell cryo-banking in high-value biotechnologies.

\section{Executive summary}

A key limiting step in the development of novel advanced cell therapies is having the ability to store \& ship cell-based medicines in a viable yet stable state

- Shipment of nonfrozen materials is challenging, and local manufacture of a cell therapy requires demonstration of product comparability at different manufacturing sites.

- The diversity and complexity of cell therapies therefore demands new cryopreservation methodologies and cryoprotectants.

Dimethyl sulfoxide has been the cryoprotectant of choice for most animal cell cryopreservation protocols since the early history of cryopreservation technology

- Clinical experience in transplantation and transfusion over more than 40 years has shown that dimethyl sulfoxide (DMSO) can be used safely and effectively.

- Nevertheless, it can affect the phenotype and genotype for both mammalian and nonmammalian cells and exhibit apparent toxicity in patients, which is driving the search for less cytotoxic cryoprotectants.

In this review, we evaluate the history of clinical use of DMSO \& seeks to explain the 3Rs for use of DMSO: reduction, removal \& replacement

- We consider the adverse events that may be associated with the toxicity of DMSO in the context of its effectiveness, reviewing the real incidence of adverse effects in patients and the probable causes.

- We review the key approaches already in use as a means of reducing its toxic effects by reduction of DMSO concentration, removal of DMSO from cell preparation post-thaw and alternative cryoprotectants are considered and assessed in terms of their progression to suitability for clinical use.

Conclusion

- DMSO has long served to enable cells to be stored for future use and continues to be the cryoprotectant of first choice.

- Replacement cryoprotectants are being developed but are yet to make significant impact in cell therapies.

I Buriak: drafting, reviewing and approving manuscript. R Fleck: drafting, reviewing, approving manuscript. J Kerby: reviewing, editing and approving manuscript. M Awan: reviewing, editing and approving manuscript. P Mericka: drafting, reviewing and approving manuscript. A Petrenko drafting, reviewing and approving manuscript. Y Petrenko: drafting, reviewing manuscript, approving manuscript. O Rogulska: drafting, reviewing and approving manuscript. G Stacey: drafting text and compiling author input. A Stolzing: drafting, reviewing, approving manuscript. 


\section{Acknowledgments}

Concepts for this review arose from discussions within the Society for Low Temperature Biology and UNESCO Chair in Cryobiology. Thanks also to the suppliers who provided additional information: AMSBio, Biolamina, Biolife, Reprocell, STEMCELL Technologies, and Zenoaq.

Financial \& competing interests disclosure

M Lowdell is co-founder of Achilles Tx, Ltd, co-founder of INmune Bio, Inc., consultant to NWBio, Inc., consultant to Autolus, Ltd, consultant to Avectas, Ltd, co-founder of Stem Cell Technologies, Ltd, stock holder of Achilles Tx, Ltd, Autolous, Ltd, INmune Bio, Inc., NWBio, Inc., Cell Medica, Ltd. G Stacey's spouse is an employee of Stem Cell Technologies. Reimbursed scientific pursuits with: SSCBio Ltd, Foundation for Biological Research and Innovation, Japan; Bluerock Therapeutics, Boston, USA; Fraunhofer IBMT, Sarbrucken, Germany. The authors have no other relevant affiliations or financial involvement with any organization or entity with a financial interest in or financial conflict with the subject matter or materials discussed in the manuscript apart from those disclosed.

No writing assistance was utilized in the production of this manuscript.

\section{Open access}

This work is licensed under the Attribution-NonCommercial-NoDerivatives 4.0 Unported License. To view a copy of this license, visit http://creativecommons.org/licenses/by-nc-nd/4.0/

\section{References}

Papers of special note have been highlighted as: • of interest

1. Lovelock JE, Bishop MWH. Prevention of freezing damage to living cells by dimethyl sulphoxide. Nature 183(4672), 1394-1395 (1959).

- Rationale for the original selection of dimethyl sulfoxide (DMSO) as a cryoprotective agent (CPA).

2. MacGregor WS. The chemical and physical properties of DMSO. Ann. NY Acad. Sci. 141(1 Biological Ac), 3-12 (1967).

3. Rammler DH, Zaffaroni A. Biological implications of DMSO based on a review of its chemical properties. Ann. NY Acad. Sci. 141(1 Biological Ac), 13-23 (1967).

4. Szmant HH. Physical properties of dimethyl sulfoxide and its function in biological systems. Ann. NY Acad. Sci. 243(1), 20-23 (1975).

5. Brayton CF. Dimethyl sulfoxide (DMSO): a review. Cornell Vet. 76(1), 61-90 (1986).

- Describes the fundamental mode of action of DMSO.

6. Ashwood-Smith MJ, Bridges BA. On the sensitivity of frozen micro-organisms to ultraviolet radiation. Proc. R. Soc. London. Ser. B. Biol. Sci. 168(1011), 194-202 (1967).

7. David NA. The pharmacology of dimethyl sulfoxide. Annu. Rev. Pharmacol. 12(1), 353-374 (1972).

8. Pope DC, Oliver WT. Dimethyl sulfoxide (DMSO). Can. J. Comp. Med. Vet. Sci. 30(1), 3 (1966).

9. Shu Z, Heimfeld S, Gao D. Hematopoietic SCT with cryopreserved grafts: adverse reactions after transplantation and cryoprotectant removal before infusion. Bone Marrow Transplant. 49(4), 469-476 (2014).

10. Momose Y, Matsumoto R, Maruyama A, Yamaoka M. Comparative analysis of transcriptional responses to the cryoprotectants, dimethyl sulfoxide and trehalose, which confer tolerance to freeze-thaw stress in Saccharomyces cerevisiae. Cryobiology 60(3), 245-261 (2010).

11. Lampugnani MG, Pedenovi M, Niewiarowski A et al. Effects of dimethyl sulfoxide (DMSO) on microfilament organization, cellular adhesion, and growth of cultured mouse B16 melanoma cells. Exp. Cell Res. 172(2), 385-396 (1987).

12. Davidson AF, Glasscock C, McClanahan DR, Benson JD, Higgins AZ. Toxicity minimized cryoprotectant addition and removal procedures for adherent endothelial cells. PLoS ONE 10(11), e0142828 (2015).

13. Trubiani O, Salvolini E, Staffolani R, Di Primio R, Mazzanti L. DMSO modifies structural and functional properties of RPMI-8402 cells by promoting programmed cell death. Int. J. Immunopathol. Pharmacol. 16(3), 253-259 (2003).

14. Trubiani O, Ciancarelli M, Di Primio R. Cell differentiation is associated to DMSO-induced programmed cell death. Biochem. Soc. Trans. 24(4), S555 (1996).

15. Trubiani O, Ciancarelli M, Rapino M, Di Primio R. Dimethyl sulfoxide induces programmed cell death and reversible G1 arrest in the cell cycle of human lymphoid pre-T cell line [Internet]. 50(1-2), 51-57 (1996).

16. Trubiani O, Pieri C, Rapino M, Di Primio R. The $c-m y c$ gene regulates the polyamine pathway in DMSO-induced apoptosis. Cell Prolif. 32(2-3), 119-129 (1999).

17. Galvao J, Davis B, Tilley M, Normando E, Duchen MR, Cordeiro MF. Unexpected low-dose toxicity of the universal solvent DMSO. FASEB J. 28(3), 1317-1330 (2014).

18. Hanslick JL, Lau K, Noguchi KK et al. Dimethyl sulfoxide (DMSO) produces widespread apoptosis in the developing central nervous system. Neurobiol. Dis. 34(1), 1-10 (2009). 
19. Yuan C, Gao J, Guo J et al. Dimethyl sulfoxide damages mitochondrial integrity and membrane potential in cultured astrocytes. PLoS ONE 9(9), e107447 (2014).

20. Banič B, Nipič D, Suput D, I M. DMSO modulates the pathway of apoptosis triggering. Cell. Mol. Biol. Lett. 16(2), 328-341 (2011).

21. Timm M, Saaby L, Moesby L, Hansen EW. Considerations regarding use of solvents in in vitro cell based assays. Cytotechnology. 65(5), 887-894 (2013).

22. Yi X, Liu M, Luo Q et al. Toxic effects of dimethyl sulfoxide on red blood cells, platelets, and vascular endothelial cells in vitro. FEBS Open Bio., 7(4), 485-494 (2017).

23. Hajighasemi F, Tajik S. Assessment of cytotoxicity of dimethyl sulfoxide in human hematopoietic tumor cell lines. Iran. J. Blood Cancer. 9(2), 48-52 (2017).

24. Sun H, Wang Y. Apoptosis of human leukemic HL-60 cells induced to differentiate by treatment with RA or DMSO. Cell Res., (2), 181-186 (1995).

25. Trivedi AB, Kitabatake N, Doi E. Toxicity of dimethyl sulfoxide as a solvent in bioassay system with HeLa cells evaluated colorimetrically with 3-(4,5-dimethyl thiazol-2-yl)-2,5-diphenyl-tetrazolium bromide. Agric. Biol. Chem. 54(11), 2961-2966 (1990).

26. Da Violante G, Zerrouk N, Richard I, Provot G, Chaumeil JC, Arnaud P. Evaluation of the cytotoxicity effect of dimethyl sulfoxide (DMSO) on Caco2/TC7 colon tumor cell cultures. Biol. Pharm. Bull. 25(12), 1600-1603 (2002).

27. Kita H, Okamoto K, Kushima R, Kawauchi A, Chano T. Dimethyl sulfoxide induces chemotherapeutic resistance in the treatment of testicular embryonal carcinomas. Oncol. Lett. 10(2), 661-666 (2015).

28. Farrant J. Pharmacological actions and toxicity of dimethyl sulphoxide and other compounds which protect smooth muscle during freezing and thawing. J. Pharm. Pharmacol. 16(7), 472-483 (1964).

- $\quad$ Early description of cytotoxic effects of DMSO.

29. Ashwood-Smith MJ. Low temperature preservation of mouse lymphocytes with dimethyl sulfoxide. Blood 23(4), 494-501 (1964).

- Early description of use of DMSO for successful reservation of mammalian cells.

30. Lionetti FJ, Hunt SM, Gore JM, Curby WA. Cryopreservation of human granulocytes. Cryobiology 12(3), 181-191 (1975).

31. Miller RA, Bean MA, Kodera Y, Herr HW. Cryopreservation of human effector cells active in antibody-dependent cell-mediated cytotoxicity. Transplantation 21(6), 517-519 (1976).

32. Ragab AH, Gilkerson E, Myers M. Factors in the cryopreservation of bone marrow cells from children with acute lymphocytic leukemia. Cryobiology 14(2), 125-134 (1977).

33. Wells SA, Christiansen C. The transplanted parathyroid gland: evaluation of cryopreservation and other environmental factors which affect its function. Surgery 75(1), 49-55 (1974).

34. Dent TL, Weber TR, Lindenauer SM et al. Cryopreservation of vein grafts. Surg. Forum. 25(0), 241-243 (1974).

35. Graham-Pole J, Davie M, Willoughby ML. Cryopreservation of human granulocytes in liquid nitrogen. J. Clin. Pathol. 30(8), 758-762 (1977).

36. Windrum P, Morris TCM, Drake MB, Niederwieser D, Ruutu T. Variation in dimethyl sulfoxide use in stem cell transplantation: a survey of EBMT centres. Bone Marrow Transplant. 36(7), 601-603 (2005)

37. Ruiz-Delgado GJ, Mancías-Guerra C, Tamez-Gómez EL et al. Dimethyl sulfoxide-induced toxicity in cord blood stem cell transplantation: report of three cases and review of the literature. Acta Haematol. 122(1), 1-5 (2009).

- An example of reports of DMSO toxicity in patients.

38. Nusbaumer D, Cunha LM da, Wedekind C. Comparing methanol-glucose and dimethyl-sulfoxide based extender for milt cryopreservation of brown trout (Salmo trutta). BioRxiv.doi: https://doi.org/10.1101/289736 289736 (2018).

39. Aramli MS, Golshahi K, Nazari RM, Aramli S, Banan A. Effectiveness of glucose-methanol extender for cryopreservation of Huso huso spermatozoa. Anim. Reprod. Sci. 162, 37-42 (2015).

40. Zhang M, Oldenhof H, Sydykov B, Bigalk J, Sieme H, Wolkers WF. Freeze-drying of mammalian cells using trehalose: preservation of DNA integrity. Sci. Rep. 7(1), 6198 (2017).

41. Rowley SD, Anderson GL. Effect of DMSO exposure without cryopreservation on hematopoietic progenitor cells. Bone Marrow Transplant. 11(5), 389-393 (1993).

42. Branch DR, Calderwood S, Cecutti MA, Herst R, Solh H. Hematopoietic progenitor cells are resistant to dimethyl sulfoxide toxicity. Transfusion 34(10), 887-890 (1994).

43. Mitrus I, Smagur A, Fidyk W et al. Reduction of DMSO concentration in cryopreservation mixture from $10 \%$ to $7.5 \%$ and $5 \%$ has no impact on engraftment after autologous peripheral blood stem cell transplantation: results of a prospective, randomized study. Bone Marrow Transpl. 53(3), 274-280 (2018).

44. Bakken AM, Bruserud O, Abrahamsen JF. No differences in colony formation of peripheral blood stem cells frozen with $5 \%$ or $10 \%$ dimethyl sulfoxide. J. Hematother. Stem Cell Res. 12(3), 351-358 (2003). 
45. Abrahamsen JF, Bakken AM, Bruserud O. Cryopreserving human peripheral blood progenitor cells with 5-percent rather than 10-percent DMSO results in less apoptosis and necrosis in CD34+ cells. Transfusion 42(12), 1573-1580 (2002).

46. Abrahamsen JF, Rusten L, Bakken AM, Bruserud O. Better preservation of early hematopoietic progenitor cells when human peripheral blood progenitor cells are cryopreserved with 5 percent dimethylsulfoxide instead of 10 percent dimethylsulfoxide. Transfusion 44(5), 785-789 (2004).

47. Tunçer S, Gurbanov R, Sheraj I, Solel E, Esenturk O, Banerjee S. Low dose dimethyl sulfoxide driven gross molecular changes have the potential to interfere with various cellular processes. Sci. Rep. 8(1), 14828 (2018).

48. Pal R, Mamidi MK, Das AK, Bhonde R. Diverse effects of dimethyl sulfoxide (DMSO) on the differentiation potential of human embryonic stem cells. Arch. Toxicol. 86(4), 651-661 (2012).

49. Vincent C, Pickering SJ, Johnson MH, Quick SJ. Dimethylsulphoxide affects the organisation of microfilaments in the mouse oocyte. Mol. Reprod. Dev. 26(3), 227-235 (1990).

50. Johnson MH, Pickering SJ. The effect of dimethylsulphoxide on the microtubular system of the mouse oocyte. Development 100(2), 313-324 (1987).

51. Chetty S, Pagliuca FW, Honore C, Kweudjeu A, Rezania A, Melton DA. A simple tool to improve pluripotent stem cell differentiation. Nat. Methods. 10(6), 553 (2013).

52. Robey P. "Mesenchymal stem cells": fact or fiction, and implications in their therapeutic use. F1000Research doi:10.12688/f1000research.10955.1 (2017).

53. Santos NC, Figueira-Coelho J, Martins-Silva J, Saldanha C. Multidisciplinary utilization of dimethyl sulfoxide: pharmacological, cellular, and molecular aspects. Biochem. Pharmacol. 65(7), 1035-1041 (2003).

54. Czysz K, Minger S, Thomas N. DMSO efficiently down regulates pluripotency genes in human embryonic stem cells during definitive endoderm derivation and increases the proficiency of hepatic differentiation. PLoS ONE 10(2), e0117689 (2015).

55. Borisov PA, Dimitrov AY, Ostankov MV, Goltsev AN. Effect of different DMSO concentrations on expression level of stemness genes in mice fetal liver stem cells prior to and after cryopreservation. Probl. Cryobiol. Cryomed. 24(2), 185-185 (2014).

56. Goltsev A, Gordiyenko Y, Rossokha I et al. Model of track formation by a bone marrow adhesive cell moving on a substrate surface [Internet]. In: AIP Conference Proceedings, American Institute of Physics (2010).2123-2126.

57. Karow AM, Abouna GJM, Humphries AL. Cryopreservation: pharmacological considerations [Internet]. In: Organ Preservation for Transplantation, Little, Brown (1974).86-107.

58. Eroglu A. Cryopreservation of mammalian oocytes by using sugars: intra- and extracellular raffinose with small amounts of dimethylsulfoxide yields high cryosurvival, fertilization, and development rates. Cryobiology 60(3), S54-S59 (2010).

59. Miao S, Mills S, Stanton C, Fitzgerald GF, Roos Y, Ross RP. Effect of disaccharides on survival during storage of freeze dried probiotics. Dairy Sci. Technol. 88(1), 19-30 (2008).

60. Solocinski J, Osgood Q, Wang M, Connolly A, Menze MA, Chakraborty N. Effect of trehalose as an additive to dimethyl sulfoxide solutions on ice formation, cellular viability, and metabolism. Cryobiology 75, 134-143 (2017).

61. Chiu P-L, Kelly DF, Walz T. The use of trehalose in the preparation of specimens for molecular electron microscopy. Micron 42(8), 762-772 (2011).

62. Crowe LM, Reid DS, Crowe JH. Is trehalose special for preserving dry biomaterials? Biophys. J. 71(4), 2087-2093 (1996).

63. Jain NK, Roy I. Trehalose and Protein Stability [Internet]. In: Current Protocols in Protein Science, John Wiley \& Sons, Inc, NJ, USA, 4.9.1-4.9.12 (2010)..

64. Kilburn D, Townrow S, Meunier V, Richardson R, Alam A, Ubbink J. Organization and mobility of water in amorphous and crystalline trehalose. Nat. Mater. 5(8), 632-635 (2006).

65. Pu LLQ, Cui X, Fink BF, Gao D, Vasconez HC. Adipose aspirates as a source for human processed lipoaspirate cells after optimal cryopreservation. Plast. Reconstr. Surg. 117(6), 1845-1850 (2006).

66. De Rosa A, De Francesco F, Tirino V et al. A new method for cryopreserving adipose-derived stem cells: an attractive and suitable large-scale and long-term cell banking technology. Tissue Eng. Part C Methods. 15(4), 659-667 (2009).

67. Rodrigues JP, Paraguassú-Braga FH, Carvalho L, Abdelhay E, Bouzas LF, Porto LC. Evaluation of trehalose and sucrose as cryoprotectants for hematopoietic stem cells of umbilical cord blood. Cryobiology 56(2), 144-151 (2008).

68. Motta JPR, Paraguassú-Braga FH, Bouzas LF, Porto LC. Evaluation of intracellular and extracellular trehalose as a cryoprotectant of stem cells obtained from umbilical cord blood. Cryobiology 68(3), 343-348 (2014).

69. Petrenko YA, Jones DRE, Petrenko AY. Cryopreservation of human fetal liver hematopoietic stem/progenitor cells using sucrose as an additive to the cryoprotective medium. Cryobiology 57(3), 195-200 (2008).

70. Mantri S, Kanungo S, Mohapatra PC. Cryoprotective effect of disaccharides on cord blood stem cells with minimal use of DMSO. Indian J. Hematol. Blood Transfus. 31(2), 206-212 (2015).

71. Yang B, Liu B, Zhou X, Shen L, Huang D. Enhanced metabolic function of human hepatocytes cryopreserved with low concentration $\mathrm{Me} 2 \mathrm{SO}$ and polyol additives at $-80^{\circ} \mathrm{C}$ [Internet]. Cryoletters 34(4), 381-387 (2015). 
72. Cardoso LM da F, Pinto MA, Henriques Pons A, Alves LA. Cryopreservation of rat hepatocytes with disaccharides for cell therapy. Cryobiology 78, 15-21 (2017).

73. Seo JM, Sohn MY, Suh JS, Atala A, Yoo JJ, Shon Y-H. Cryopreservation of amniotic fluid-derived stem cells using natural cryoprotectants and low concentrations of dimethylsulfoxide. Cryobiology 62(3), 167-173 (2011).

74. Zhou X, Yuan J, Liu J, Liu B. Loading trehalose into red blood cells by electroporation and its application in freeze-drying. Cryo Letters 31(2), 147-156 (2010).

75. Weaver JC. Electroporation: a general phenomenon for manipulating cells and tissues. J. Cell. Biochem. 51(4), 426-435 (1993).

76. Dovgan B, Barlič A, Knežević M, Miklavčič D. Cryopreservation of human adipose-derived stem cells in combination with trehalose and reversible electroporation. J. Membr. Biol. 250(1), 1-9 (2017).

77. Acker JP, Lu X, Young V et al. Measurement of trehalose loading of mammalian cells porated with a metal-actuated switchable pore. Biotechnol. Bioeng. 82(5), 525-532 (2003).

78. Kikawada T, Saito A, Kanamori Y et al. Trehalose transporter 1, a facilitated and high-capacity trehalose transporter, allows exogenous trehalose uptake into cells. Proc. Natl Acad. Sci. USA 104(28), 11585-11590 (2007).

79. Oliver AE, Jamil K, Crowe JH, Tablin F. Loading human mesenchymal stem cells with trehalose by fluid-phase endocytosis. Cell Preserv. Technol. 2(1), 35-49 (2004).

80. Campbell LH, Brockbank KGM. Culturing with trehalose produces viable endothelial cells after cryopreservation. Cryobiology 64(3), 240-244 (2012).

81. Petrenko YA, Rogulska OY, Mutsenko VV, Petrenko AY. A sugar pretreatment as a new approach to the Me2SO- and xeno-free cryopreservation of human mesenchymal stromal cells. Cryo Letters 35(3), 239-246 (2014).

- A seminal description of the development of a DMSO reduction strategy.

82. Rogulska O, Petrenko Y, Petrenko A. DMSO-free cryopreservation of adipose-derived mesenchymal stromal cells: expansion medium affects post-thaw survival. Cytotechnology. 69(2), 265-276 (2017).

83. Fuller BJ. Cryoprotectants: the essential antifreezes to protect life in the frozen state. CryoLetters 25(6), 375-388 (2004).

84. Zhao J, Hao H-N, Thomas RL, Lyman WD. An efficient method for the cryopreservation of fetal human liver hematopoeitic progenitor cells. Stem Cells 19(3), 212-218 (2001).

85. Mitchell A, Rivas KA, Smith R III, Watts AE. Cryopreservation of equine mesenchymal stem cells in $95 \%$ autologous serum and $5 \%$ DMSO does not alter post-thaw growth or morphology in vitro compared to fetal bovine serum or allogeneic serum at 20 or $95 \%$ and DMSO at 10 or 5\%. Stem Cell Res. Ther. 6, 231 (2015).

86. Terada S, Nishimura T, Sasaki M, Yamada H, Miki M. Sericin, a protein derived from silkworms, accelerates the proliferation of several mammalian cell lines including a hybridoma. Cytotechnology. 40(1/3), 3-12 (2002).

87. Cao T-T, Zhang Y-Q. The potential of silk sericin protein as a serum substitute or an additive in cell culture and cryopreservation. Amino Acids 49(6), 1029-1039 (2017).

88. Sasaki M, Kato Y, Yamada H, Terada S. Development of a novel serum-free freezing medium for mammalian cells using the silk protein sericin. Biotechnol. Appl. Biochem. 42(2), 183 (2005).

89. Miyamoto Y, Teramoto N, Hayashi S, Enosawa S. An improvement in the attaching capability of cryopreserved human hepatocytes by a proteinaceous high molecule, sericin, in the serum-free solution. Cell Transplant. 19(6-7), 701-706 (2010).

90. Verdanova M, Pytlik R, Kalbacova MH. Evaluation of sericin as a fetal bovine serum-replacing cryoprotectant during freezing of human mesenchymal stromal cells and human osteoblast-like cells. Biopreserv. Biobank. 12(2), 99 (2014).

91. Ohnishi K, Murakami M, Morikawa M, Yamaguchi A. Effect of the silk protein sericin on cryopreserved rat islets. J. Hepatobiliary. Pancreat. Sci. 19(4), 354-360 (2012).

92. Nakasato SK. Evaluation of hetastarch. Clin. Pharm. 1(6), 509-514.

93. Stolzing A, Naaldijk Y, Fedorova V, Sethe S. Hydroxyethylstarch in cryopreservation - mechanisms, benefits and problems. Transfus. Apher. Sci. 46(2), 137-147 (2012).

94. Pasch J, Schiefer A, Heschel I, Rau G. Cryopreservation of keratinocytes in a monolayer. Cryobiology 39(2), 158-168 (1999).

95. Pasch J, Schiefer A, Heschel I, Dimoudis N, Rau G. Variation of the HES concentration for the cryopreservation of keratinocytes in suspensions and in monolayers. Cryobiology 41(2), 89-96 (2000).

96. Persidsky MD, Ellett MH. Hydroxyethyl starch as a cryopreservative for nucleated mammalian cells. Cryobiology 8(6), 586-588 (1971).

97. Ashwood-Smith MJ, Warby C, Connor KW, Becker G. Low-temperature preservation of mammalian cells in tissue culture with polyvinylpyrrolidone (PVP), dextrans, and hydroxyethyl starch (HES). Cryobiology 9(5), 441-449 (1972).

98. Allen ED, Weatherbee L, Spencer HH, Lindenauer SM, Permoad PA. Large unit red cell cryopreservation with hydroxyethyl starch. Cryobiology 13(5), 500-506 (1976).

99. Sputtek A, Singbartl G, Langer R, et al. Cryopreservation of red blood cells with the nonpenetrating cryoprotectant hydroxyethyl starch. CryoLetters 16, 283-288 (1995). 
100. Pogozhykh D, Pakhomova Y, Pervushina O, Hofmann N, Glasmacher B, Zhegunov G. Exploring the possibility of cryopreservation of feline and canine erythrocytes by rapid freezing with penetrating and non-penetrating cryoprotectants. PLoS ONE 12(1), e0169689 (2017).

101. Takahashi T, Hirsh A, Erbe E, Williams RJ. Mechanism of cryoprotection by extracellular polymeric solutes. Biophys. J. 54(3), 509-518 (1988).

102. Naaldijk Y, Staude M, Fedorova V, Stolzing A. Effect of different freezing rates during cryopreservation of rat mesenchymal stem cells using combinations of hydroxyethyl starch and dimethylsulfoxide. BMC Biotechnol. 12(1), 49 (2012).

103. Naaldijk Y, Johnson AA, Friedrich-Stöckigt A, Stolzing A. Cryopreservation of dermal fibroblasts and keratinocytes in hydroxyethyl starch-based cryoprotectants. BMC Biotechnol. 16(1), 85 (2016).

104. Strobel J, Hohensee F, Kuta P, Eckstein R, Zingsem J. Comparison of six different cryoprotective agents used for deep freezing and storage of CD34+ cells derived from cord blood and peripheral blood stem cell concentrates. Clin. Lab. 63(03/2017), (2017).

- A modern study that demonstrates a good approach to comparison of different CPA admixtures.

105. Stiff PJ, Murgo AJ, Zaroulis CG, DeRisi MF, Clarkson BD. Unfractionated human marrow cell cryopreservation using dimethylsulfoxide and hydroxyethyl starch. Cryobiology 20(1), 17-24 (1983).

106. Ide K, Matsuura S, Fujino Y, Ohno K, Tsujimoto H. Investigation of various methods for the cryopreservation of canine bone marrow-derived CD34+ cells. J. Vet. Med. Sci. 70(11), 1211-1217 (2008).

107. Hayakawa J, Joyal EG, Gildner JF et al. 5\% dimethyl sulfoxide (DMSO) and pentastarch improves cryopreservation of cord blood cells over 10\% DMSO. Transfusion 50(10), 2158-2166 (2010).

108. Rowley SD, Feng Z, Chen L et al. A randomized Phase III clinical trial of autologous blood stem cell transplantation comparing cryopreservation using dimethylsulfoxide vs dimethylsulfoxide with hydroxyethylstarch. Bone Marrow Transplant. 31(11), 1043-1051 (2003).

109. Ashwood-Smith MJ. Current concepts concerning radioprotective and cryoprotective properties of dimethyl sulfoxide in cellular systems. Ann. NY Acad. Sci. 243(1), 246-256 (1975).

110. Petrenko YA. Cryopreservation of human embryonic liver cells using DMSO and high molecular weight polymers. Probl. Cryobiol. Cryomedicine. 0(3), 80-87 (2003).

111. E Makashova O, O Babijchuk OB, L Zubova O, M Zubov P. Optimization of cryopreservation technique for human cord blood nucleated cells using combination of cryoprotectant DMSO and antioxidant N-acetyl-L-cysteine. Probl. Cryobiol. Cryomedicine. 26(4), 295-307 (2016).

112. Fuller BJ, Shurey C, Lane N, Petrenko A, Green C. Hypothermic renal preservation with a sucrose/polyethylene glycol solution in a rabbit renal transplant model. Cryo Letters 27(2), 127-132 (2006).

113. Semenchenko OA, Cherkashina DV, Tkacheva EN, Lebedinsky AS, Fuller BJ, Petrenko AY. 160. Sucrose-based preservation solution modified by PEG-8000 for cold storage of isolated rat liver. Cryobiology 53(3), 434-435 (2006).

114. Babijchuk LA, Zemlianskykh NG. Optimization and advantages of washing-out method for erythrocytes cryopreservation with PEO-1500. Probl Cryobiol. 1, 35-41 (2001).

115. Monroy B. Use of polyethyleneglycol for porcine islet cryopreservation. Cell Transplant. 6(6), 613-621 (1997).

116. El-Shewy HM, William FK, Darrabie M, Collins BH, Opara EC. Polyvinyl pyrrolidone: a novel cryoprotectant in islet cell cryopreservation. Cell Transplant. 13(3), 237-243 (2004).

117. Davies M, Huynh TT, Fulton G, Svendsen E, Brockbank FG, Hagen P-O. Controlling transplant vasculopathy in cryopreserved vein grafts with polyethylene glycol and glutathione during transport. Eur. J. Vasc. Endovasc. Surg. 17(6), 493-500 (1999).

118. Liu Y, Xu X, Ma XH, Liu J, Cui ZF. Effect of various freezing solutions on cryopreservation of mesenchymal stem cells from different animal species. Cryo Letters. 32(5), 425-435 (2011).

119. Liu Y, Xu X, Ma X, Martin-Rendon E, Watt S, Cui Z. Cryopreservation of human bone marrow-derived mesenchymal stem cells with reduced dimethylsulfoxide and well-defined freezing solutions. Biotechnol. Prog. 26(6), 1635-1643 (2010).

120. Lee Y-A, Kim Y-H, Kim B-J et al. Cryopreservation of mouse spermatogonial stem cells in dimethylsulfoxide and polyethylene glycol1. Biol. Reprod. 89(5), 1-9 (2013).

121. Mizrahi A, Moore GE. Partial substitution of serum in hematopoietic cell line media by synthetic polymers. Appl. Microbiol. 19(6), 906-910 (1970).

122. Merten O-W, Petres S, Couvé E. A simple serum-free freezing medium for serum-free cultured cells. Biologicals 23(2), 185-189 (1995).

123. Ohno T, Kurita K, Abe S, Eimori N, Ikawa Y. A simple freezing medium for serum-free cultured cells. Cytotechnology 1(3), 257-260 (1988).

124. Thirumala S, Gimble JM, Devireddy RV. Evaluation of methylcellulose and dimethyl sulfoxide as the cryoprotectants in a serum-free freezing media for cryopreservation of adipose-derived adult stem cells. Stem Cells Dev. 19(4), 513-522 (2010).

125. Thirumala S, Wu X, Gimble JM, Devireddy RV. Evaluation of polyvinylpyrrolidone as a cryoprotectant for adipose tissue-derived adult stem cells. Tissue Eng. Part C Methods. 16(4), 783-792 (2010). 
126. Shivakumar SB, Bharti D, Jang SJ et al. Cryopreservation of human wharton's jelly-derived mesenchymal stem cells following controlled rate freezing protocol using different cryoprotectants; a comparative study. Int. J. Stem Cells. 8(2), 155-169 (2015).

127. Thirumala S, Gimble JM, Devireddy RV. Cryopreservation of stromal vascular fraction of adipose tissue in a serum-free freezing medium. J. Tissue Eng. Regen. Med. 4(3), 224-232 (2010).

128. Loretz LJ, Li AP, Flye MW, Wilson AGE. Optimization of cryopreservation procedures for rat and human hepatocytes. Xenobiotica 19(5), 489-498 (1989).

129. Gómez-Lechón MJ, Lahoz A, Jiménez N, Vicente Castell J, Donato MT. Cryopreservation of rat, dog and human hepatocytes: influence of preculture and cryoprotectants on recovery, cytochrome P450 activities and induction upon thawing. Xenobiotica 36(6), 457-472 (2006).

130. Miyagi-Shiohira C, Kurima K, Kobayashi N et al. Cryopreservation of adipose-derived mesenchymal stem cells. Cell Med. 8(1-2), 3-7 (2015).

131. Matsumura K, Hayashi F, Nagashima T, Hyon SH. Long-term cryopreservation of human mesenchymal stem cells using carboxylated poly-l-lysine without the addition of proteins or dimethyl sulfoxide. J. Biomater. Sci. Polym. Ed. 24(12), 1484-1497 (2013).

132. Naaldijk Y, Friedrich-Stöckigt A, Sethe S, Stolzing A. Comparison of different cooling rates for fibroblast and keratinocyte cryopreservation. J. Tissue Eng. Regen. Med. 10(10), E354-E364 (2016).

133. Meryman HT. Cryopreservation of living cells: principles and practice. Transfusion 47(5), 935-945 (2007).

134. Elliott GD, Wang S, Fuller BJ. Cryoprotectants: a review of the actions and applications of cryoprotective solutes that modulate cell recovery from ultra-low temperatures. Cryobiology 76, 74-91 (2017).

135. Davidson AF, Benson JD, Higgins AZ. Mathematically optimized cryoprotectant equilibration procedures for cryopreservation of human oocytes. Theor. Biol. Med. Model. 11, 13 (2014).

136. D Benson J. Modeling and optimization of cryopreservation [Internet]. Springer, NY, USA, 83-120 (2015).

137. Morris C, de Wreede L, Scholten M et al. Should the standard dimethyl sulfoxide concentration be reduced? Results of a European Group for Blood and Marrow Transplantation prospective noninterventional study on usage and side effects of dimethyl sulfoxide. Transfusion 54(10), 2514-2522 (2014).

138. Rubinstein P, Dobrila L, Rosenfield RE et al. Processing and cryopreservation of placental/umbilical cord blood for unrelated bone marrow reconstitution. Proc. Natl Acad. Sci. USA 92(22), 10119-10122 (1995).

139. Beaujean F, Hartmann O, Kuentz M, Le Forestier C, Divine M, Duedari N. A simple efficient washing procedure for cryopreserved human hematopoietic stem cells prior to reinfusion. Bone Marrow Transplant. 8(4), 291-294 (1991).

140. Fry LJ, Querol S, Gomez SG, McArdle S, Rees R, Madrigal JA. Assessing the toxic effects of DMSO on cord blood to determine exposure time limits and the optimum concentration for cryopreservation. Vox Sang. 109(2), 181-190 (2015).

141. Rowley SD, Feng Z, Yadock D, Holmberg L, MacLeod B, Heimfeld S. Post-thaw removal of DMSO does not completely abrogate infusional toxicity or the need for pre-infusion histamine blockade. Cytotherapy 1(6), 439-446 (1999).

142. Decot V, Houzé P, Stoltz J-F, Bensoussan D. Quantification of residual dimethylsulfoxide after washing cryopreserved stem cells and thawing tissue grafts. Biomed. Mater. Eng. 19(4-5), 293-300 (2009).

143. Rodriguez L, Azqueta C, Azzalin S, Garcia J, Querol S. Washing of cord blood grafts after thawing: high cell recovery using an automated and closed system*. Vox Sang. 87(3), 165-172 (2004).

144. Scerpa MC, Daniele N, Landi F et al. Automated washing of human progenitor cells: evaluation of apoptosis and cell necrosis. Transfus. Med. 21(6), 402-407 (2011).

145. Zhu F, Heditke S, Kurtzberg J et al. Hydroxyethyl starch as a substitute for dextran 40 for thawing peripheral blood progenitor cell products. Cytotherapy. 17(12), 1813-1819 (2015).

146. Foïs E, Desmartin M, Benhamida S et al. Recovery, viability and clinical toxicity of thawed and washed haematopoietic progenitor cells: analysis of 952 autologous peripheral blood stem cell transplantations. Bone Marrow Transplant. 40(9), 831-835 (2007).

147. Abonnenc M, Pesse B, Tissot J-D, Barelli S, Lion N. Automatic washing of thawed haematopoietic progenitor cell grafts: a preclinical evaluation. Vox Sang. 112(4), 367-378 (2017).

148. Valeri CR, Ragno G, Van Houten P et al. Automation of the glycerolization of red blood cells with the high-separation bowl in the Haemonetics ACP 215 instrument. Transfusion 45(10), 1621-1627 (2005).

149. Calmels B, Houzé P, Hengesse J-C, Ducrot T, Malenfant C, Chabannon C. Preclinical evaluation of an automated closed fluid management device: cytomateTM, for washing out DMSO from hematopoietic stem cell grafts after thawing. Bone Marrow Transplant. 31(9), 823-828 (2003)

150. Perotti CG, Fante C Del, Viarengo G et al. A new automated cell washer device for thawed cord blood units. Transfusion 44(6), 900-906 (2004).

151. Lemarie C, Calmels B, Malenfant C et al. Clinical experience with the delivery of thawed and washed autologous blood cells, with an automated closed fluid management device: cytoMate. Transfusion 45(5), 737-742 (2005). 
152. Rodríguez L, Velasco B, García J, Martín-Henao GÁ. Evaluation of an automated cell processing device to reduce the dimethyl sulfoxide from hematopoietic grafts after thawing. Transfusion 45(8), 1391-1397 (2005).

153. Mfarrej B, Bouchet G, Couquiaud J et al. Pre-clinical assessment of the Lovo device for dimethyl sulfoxide removal and cell concentration in thawed hematopoietic progenitor cell grafts. Cytotherapy. 19(12), 1501-1508 (2017).

154. Ding W, Zhou X, Heimfeld S, Reems J-A, Gao D. A steady-state mass transfer model of removing CPAs from cryopreserved blood with hollow fiber modules. J. Biomech. Eng. 132(1), 011002 (2009).

155. Arnaud F, Kapnik E, Meryman HT. Use of hollow fiber membrane filtration for the removal of DMSO from platelet concentrates. Platelets 14(3), 131-137 (2003).

156. Bianco P, Robey PG, Simmons PJ. Mesenchymal stem cells: revisiting history, concepts, and assays. Cell Stem Cell. 2(4), 313 (2008).

157. Sipp D, Robey PG, Turner L. Clear up this stem-cell mess. Nature 561(7724), 455-457 (2018).

158. Tostoes R, Dodgson JR, Weil B, Gerontas S, Mason C, Veraitch F. A novel filtration system for point of care washing of cellular therapy products. J. Tissue Eng. Regen. Med. 11(11), 3157-3167 (2017).

159. Memon K, Cheng Y, Panhwar F et al. A low-cost easy-to-fabricate sandwich-structured microdevice for controllable removal of extracellular cryoprotective agents with high efficiency. Cryo Letters 39(1), 7-13

160. Song YS, Moon S, Hulli L, Hasan SK, Kayaalp E, Demirci U. Microfluidics for cryopreservation. Lab Chip. 9(13), 1874 (2009).

161. Hanna J, Hubel A, Lemke E. Diffusion-based extraction of DMSO from a cell suspension in a three stream, vertical microchannel. Biotechnol. Bioeng. 109(9), 2316-2324 (2012).

162. Park S, Wijethunga PAL, Moon H, Han B. On-chip characterization of cryoprotective agent mixtures using an EWOD-based digital microfluidic device. Lab Chip. 11(13), 2212-2221 (2011).

163. Fleming KK, Longmire EK, Hubel A. Numerical characterization of diffusion-based extraction in cell-laden flow through a microfluidic channel. J. Biomech. Eng. 129(5), 703 (2006).

164. Fleming Glass KK, Longmire EK, Hubel A. Optimization of a microfluidic device for diffusion-based extraction of DMSO from a cell suspension. Int. J. Heat Mass Transf. 51(23-24), 5749-5757 (2008).

165. Xu X, Liu Y, Cui ZF. Effects of cryopreservation on human mesenchymal stem cells attached to different substrates. J. Tissue Eng. Regen. Med. 8(8), 664-672 (2014).

166. Xu X, Liu Y, Cui Z, Wei Y, Zhang L. Effects of osmotic and cold shock on adherent human mesenchymal stem cells during cryopreservation. J. Biotechnol. 162(2-3), 224-231 (2012).

167. Bissoyi A, Bit A, Singh BK, Singh AK, Patra PK. Enhanced cryopreservation of MSCs in microfluidic bioreactor by regulated shear flow. Sci. Rep. 6(1), 35416 (2016).

168. Costa PF, Dias AF, Reis RL, Gomes ME. Cryopreservation of cell/scaffold tissue-engineered constructs. Tissue Eng. Part C. Methods. 18(11), 852-858 (2012).

169. Petrenko YA, Petrenko AY, Martin I, Wendt D. Perfusion bioreactor-based cryopreservation of 3D human mesenchymal stromal cell tissue grafts. Cryobiology 76, 150-153 (2017).

170. Katsen-Globa A, Meiser I, Petrenko YA et al. Towards ready-to-use 3-D scaffolds for regenerative medicine: adhesion-based cryopreservation of human mesenchymal stem cells attached and spread within alginate-gelatin cryogel scaffolds. J. Mater. Sci. Mater. Med. 25(3), 857-871 (2014).

171. Bissoyi A, Pramanik K, Panda NN, Sarangi SK. Cryopreservation of hMSCs seeded silk nanofibers based tissue engineered constructs. Cryobiology 68(3), 332-342 (2014).

172. Mutsenko V V, Gryshkov O, Lauterboeck L et al. Novel chitin scaffolds derived from marine sponge Ianthella basta for tissue engineering approaches based on human mesenchymal stromal cells: biocompatibility and cryopreservation. Int. J. Biol. Macromol. 104, 1955-1965 (2017).

173. Pasley S, Zylberberg C, Matosevic S. Natural killer-92 cells maintain cytotoxic activity after long-term cryopreservation in novel DMSO-free media. Immunol. Lett. 192, 35-41 (2017).

174. Edashige K. Permeability of the plasma membrane to water and cryoprotectants in mammalian oocytes and embryos: its relevance to vitrification. Reprod. Med. Biol. 16(1), 36-39 (2017).

175. Best BP. Cryoprotectant toxicity: facts, issues, and questions. Rejuvenation Res. 18(5), 422-436 (2015).

176. Sydykov B, Oldenhof H, de Oliveira Barros L, Sieme H, Wolkers WF. Membrane permeabilization of phosphatidylcholine liposomes induced by cryopreservation and vitrification solutions. Biochim. Biophys. Acta-Biomembr. 1860(2), 467-474 (2018).

177. Lee Y, Pincus PA, Hyeon C. Effects of dimethyl sulfoxide on surface water near phospholipid bilayers. Biophys. J. 111(11), 2481-2491 (2016).

178. Wang X, Hua T-C, Sun D-W, Liu B, Yang G, Cao Y. Cryopreservation of tissue-engineered dermal replacement in Me2SO: toxicity study and effects of concentration and cooling rates on cell viability. Cryobiology 55(1), 60-65 (2007). 
179. Babiak I, Glogowski J, Luczynski MJ, Luczynski M, Demianowicz W. The effect of egg yolk, low density lipoproteins, methylxanthines and fertilization diluent on cryopreservation efficiency of northern pike (Esox lucius) spermatozoa. Theriogenology. 52(3), 473-479 (1999).

180. Purdy PH, Graham JK. Membrane modification strategies for cryopreservation [Internet]. In: Methods in Molecular Biology (Clifton, N.J.) 337-342 (2015).

181. Xu X, Cowley S, Flaim CJ, James W, Seymour LW, Cui Z. Enhancement of cell recovery for dissociated human embryonic stem cells after cryopreservation. Biotechnol. Prog. 26(3), 781-788 (2009).

182. Du T, Chao L, Zhao $S$ et al. Successful cryopreservation of whole sheep ovary by using DMSO-free cryoprotectant. J. Assist. Reprod. Genet. 32(8), 1267-1275 (2015).

183. Shivakumar SB, Bharti D, Jang S-J et al. Cryopreservation of human Wharton's jelly-derived mesenchymal stem cells following controlled rate freezing protocol using different cryoprotectants; a comparative study. Int. J. Stem Cells. 8(2), 155-169 (2015).

184. Novogrodsky A, Ravid A, Rubin AL, Stenzel KH. Hydroxyl radical scavengers inhibit lymphocyte mitogenesis. Proc. Natl Acad. Sci. USA 79(4), 1171-1174 (1982).

185. Sanmartín-Suárez C, Soto-Otero R, Sánchez-Sellero I, Méndez-Álvarez E. Antioxidant properties of dimethyl sulfoxide and its viability as a solvent in the evaluation of neuroprotective antioxidants. J. Pharmacol. Toxicol. Methods 63(2), 209-215 (2011).

186. Simic MG, Bergtold DS, Karam LR. Generation of oxy radicals in biosystems. Mutat. Res. 214(1), 3-12 (1989).

187. Fuller B, Dijk S, Butler P, Hoang V, Davidson B. Pro-inflammatory agents accumulate during donor liver cold preservation: a study on increased adhesion molecule expression and abrogation by curcumin in cultured endothelial cells. Cryobiology 46(3), 284-288 (2003).

188. Amidi F, Pazhohan A, Shabani Nashtaei M, Khodarahmian M, Nekoonam S. The role of antioxidants in sperm freezing: a review. Cell Tissue Bank. 17(4), 745-756 (2016).

189. Xue W-J, Luo X-H, Li Y et al. Effects of astragalosides on cultured islets after cryopreservation in rats. Transplant. Proc. 43(10), 3908-3912 (2011).

190. Fang L, Bai C, Chen Y et al. Inhibition of ROS production through mitochondria-targeted antioxidant and mitochondrial uncoupling increases post-thaw sperm viability in yellow catfish. Cryobiology 69(3), 386-393 (2014).

191. Lu X, Zhang Y, Bai H, Liu J, Li J, Wu B. Mitochondria-targeted antioxidant MitoTEMPO improves the post-thaw sperm quality. Cryobiology 80, 26-29 (2018).

192. GKP D, Sc SRB, Sc ATM et al. Vitamin E supplementation in semen-freezing medium improves the motility and protects sperm from freeze-thaw - induced DNA damage. Fertil. Steril. 95(3), 1149-1151 (2011).

193. Niki E. Role of vitamin E as a lipid-soluble peroxyl radical scavenger: in vitro and in vivo evidence. Free Radic. Biol. Med. 66, 3-12 (2014).

194. Bissoyi A, Nayak B, Pramanik K, Sarangi SK. Targeting cryopreservation-induced cell death: a review. Biopreserv. Biobank. 12(1), 23-34 (2014).

195. Beirão J, Zilli L, Vilella S, Cabrita E, Schiavone R, Herráez MP. Improving sperm cryopreservation with antifreeze proteins: effect on Gilthead Seabream (Sparus aurata) plasma membrane lipids1. Biol. Reprod. 86(2), 59 (2012).

196. Biggs CI, Bailey TL, Ben Graham B, Stubbs C, Fayter A, Gibson MI. Polymer mimics of biomacromolecular antifreezes. Nat. Commun. 8(1), 1546 (2017).

197. Arutyunyan IV, Strokova SO, Makarov AV et al. DMSO-free cryopreservation of human umbilical cord tissue. Bull. Exp. Biol. Med. 166(1), 155-162 (2018).

198. Pollock K, Budenske JW, McKenna DH, Dosa PI, Hubel A. Algorithm-driven optimization of cryopreservation protocols for transfusion model cell types including Jurkat cells and mesenchymal stem cells. J. Tissue Eng. Regen. Med. 11(10), 2806-2815 (2017).

199. Svalgaard JD, Talkhoncheh MS, Haastrup EK et al. Pentaisomaltose, an alternative to DMSO. Engraftment of cryopreserved human CD34 ${ }^{+}$cells in immunodeficient NSG mice. Cell Transplant. 27(9), 1407-1412 (2018).

200. Zhai H, Yang J, Zhang J et al. Natural zwitterionic L-Carnitine as efficient cryoprotectant for solvent-free cell cryopreservation. Biochem. Biophys. Res. Commun. 489(1), 76-82 (2017).

201. Yang J, Cai N, Zhai H, Zhang J, Zhu Y, Zhang L. Natural zwitterionic betaine enables cells to survive ultrarapid cryopreservation. Sci. Rep. 6(1), 6 (2016).

202. Vrana NE, Matsumura K, Hyon S-H et al. Cell encapsulation and cryostorage in PVA-gelatin cryogels: incorporation of carboxylated E-poly-L-lysine as cryoprotectant. J. Tissue Eng. Regen. Med. 6(4), 280-290 (2012).

203. Freimark D, Sehl C, Weber C et al. Systematic parameter optimization of a Me2SO- and serum-free cryopreservation protocol for human mesenchymal stem cells. Cryobiology 63(2), 67-75 (2011).

204. Matsumura K, Bae JY, Hyon SH. Polyampholytes as cryoprotective agents for mammalian cell cryopreservation. Cell Transplant. 19(6-7), 691-699 (2010).

205. Dannull J, Haley NR, Archer G et al. Melanoma immunotherapy using mature DCs expressing the constitutive proteasome. J. Clin. Invest. 123(7), 3135-3145 (2013). 
206. Greene SJ, Epstein SE, Kim RJ et al. Rationale and design of a randomized controlled trial of allogeneic mesenchymal stem cells in patients with nonischemic cardiomyopathy. J. Cardiovasc. Med. 18(4), 283-290 (2017).

207. Safinia N, Vaikunthanathan T, Fraser $\mathrm{H}$ et al. Successful expansion of functional and stable regulatory $\mathrm{T}$ cells for immunotherapy in liver transplantation. Oncotarget. 7(7), 7563-7577 (2016).

208. Lee MC, Ha C-W, Elmallah RK et al. A placebo-controlled randomised trial to assess the effect of TGF-B1-expressing chondrocytes in patients with arthritis of the knee. Bone Joint J. 97-B(7), 924-932 (2015).

209. DiGiusto DL, Cannon PM, Holmes MC et al. Preclinical development and qualification of ZFN-mediated CCR5 disruption in human hematopoietic stem/progenitor cells. Mol. Ther. Methods Clin. Dev. 3, 16067 (2016).

210. Brown CE, Alizadeh D, Starr R et al. Regression of glioblastoma after chimeric antigen receptor T-cell therapy. N. Engl. J. Med. 375(26), 2561-2569 (2016).

211. Gardner RA, Finney O, Annesley C et al. Intent-to-treat leukemia remission by CD19 CAR T cells of defined formulation and dose in children and young adults. Blood 129(25), 3322-3331 (2017).

- A modern citation for DMSO in use for preservation of cell therapies showing it is still embedded in clinical practice and is unlikely to be replaced quickly.

212. Kastrup J, Haack-Sørensen M, Juhl M et al. Cryopreserved off-the-shelf allogeneic adipose-derived stromal cells for therapy in patients with ischemic heart disease and heart failure-a safety study. Stem Cells Transl. Med. 6(11), 1963-1971 (2017).

213. Fraser H, Safinia N, Grageda N et al. A rapamycin-based GMP-compatible process for the isolation and expansion of regulatory $\mathrm{T}$ cells for clinical trials. Mol. Ther. - Methods Clin. Dev. 8, 198-209 (2018).

214. Kilbride P, Lamb S, Milne S et al. Spatial considerations during cryopreservation of a large volume sample. Cryobiology 73(1), 47-54 (2016).

215. Creasey AA, Stacey G, Bharti K, Sato Y, Lubiniecki A. A strategic road map to filing a Biologics License Application for a pluripotent stem cell derived therapeutic product. Biologicals 59, 68-71 (2019).

216. ICH Harmonized Tripartite Guideline. Comparability of biotechnological/biological products subject to changes in their manufacturing process: ICH (2004). https://database.ich.org/sites/default/files/Q5E\%20Guideline.pdf

217. Williams DJ, Archer R, Archibald P et al. Comparability: manufacturing, characterization and controls, report of a UK Regenerative Medicine Platform Pluripotent Stem Cell Platform Workshop, Trinity Hall, Cambridge, 14-15 September 2015. Regen. Med. 11(5), 483-492 (2016).

218. ICH Harmonized Tripartite Guideline. Pharmaceutical Development: ICH (2009). https://database.ich.org/sites/default/files/Q8\%28R2\%29\%20Guideline.pdf

219. Mazur P, Leibo SP, Chu EHY. A two-factor hypothesis of freezing injury: evidence from Chinese hamster tissue-culture cells. Exp. Cell Res. 71(2), 345-355 (1972).

220. Stacey GN, Connon CJ, Coopman K et al. Preservation and stability of cell therapy products: recommendations from an expert workshop. Regen. Med. 12(5), 553-564 (2017).

- An expert workshop review making key recommendations to progress the development of preservation technologies in support of new cell-based therapies. 
